\title{
A new activity model for Fe-Mg-Al biotites: I-Derivation and calibration of mixing parameters
}

\author{
Edgar Dachs $^{1}$ (D) $\cdot$ Artur Benisek $^{1}$ (D)
}

Received: 30 July 2020 / Accepted: 29 December 2020 / Published online: 4 March 2021

(c) The Author(s) 2021

\begin{abstract}
A new activity model for $\mathrm{Fe}-\mathrm{Mg}-\mathrm{Al}$ biotites is formulated, which extends that of $\mathrm{Mg}-\mathrm{Al}$ biotites (Dachs and Benisek, Contrib Mineral Petrol 174:76, 2019) to the $\mathrm{K}_{2} \mathrm{O}-\mathrm{FeO}-\mathrm{MgO}-\mathrm{Al}_{2} \mathrm{O}_{3}-\mathrm{SiO}_{2}-\mathrm{H}_{2} \mathrm{O}$ (KFMASH) system. It has the two composition variables $X_{\mathrm{Mg}}=\mathrm{Mg} /\left(\mathrm{Mg}+\mathrm{Fe}^{2+}\right)$ and octahedral $\mathrm{Al}$, and $\mathrm{Fe}-\mathrm{Mg}$ and $\mathrm{Mg}-\mathrm{Al}$ ordering variables resulting in five linearly independent endmembers: annite (Ann, $\mathrm{K}[\mathrm{Fe}]^{\mathrm{M} 1}[\mathrm{Fe}]_{2}{ }^{\mathrm{M} 2}\left[\mathrm{Al}_{0.5} \mathrm{Si}_{0.5}\right]_{2}{ }^{\mathrm{T} 1}\left[\mathrm{Si}_{2}{ }_{2}{ }^{\mathrm{T}} \mathrm{O}_{10}(\mathrm{OH})_{2}\right.$, phlogopite $(\mathrm{Phl}$, $\mathrm{K}[\mathrm{Mg}]^{\mathrm{M} 1}[\mathrm{Mg}]_{2}{ }^{\mathrm{M} 2}\left[\mathrm{Al}_{0.5} \mathrm{Si}_{0.5}\right]_{2}{ }^{\mathrm{T} 1}\left[\mathrm{Si}_{2}{ }_{2}{ }^{\mathrm{T} 2} \mathrm{O}_{10}(\mathrm{OH})_{2}\right.$, ordered Fe-Mg biotite $\left(\mathrm{Obi}, \mathrm{K}[\mathrm{Fe}]^{\mathrm{M} 1}[\mathrm{Mg}]_{2}{ }^{\mathrm{M} 2}\left[\mathrm{Al}_{0.5} \mathrm{Si}_{0.5}\right]_{2}{ }^{\mathrm{T1}}[\mathrm{Si}]_{2}{ }^{\mathrm{T} 2} \mathrm{O}_{10}(\mathrm{OH})_{2}\right.$, ordered eastonite (Eas, $\mathrm{K}[\mathrm{Al}]^{\mathrm{M} 1}[\mathrm{Mg}]_{2}{ }^{\mathrm{M} 2}[\mathrm{Al}]_{2}{ }^{\mathrm{T} 1}[\mathrm{Si}]_{2}{ }^{\mathrm{T} 2} \mathrm{O}_{10}(\mathrm{OH})_{2}$, and disordered eastonite (Easd, $\mathrm{K}\left[\mathrm{Al}_{1 / 3} \mathrm{Mg}_{2 / 3}\right]^{\mathrm{M} 1}\left[\mathrm{Al}_{1 / 3} \mathrm{Mg}_{2 / 3}\right]_{2}{ }^{\mathrm{M} 2}[\mathrm{Al}]_{2}{ }^{\mathrm{T} 1}[\mathrm{Si}]_{2}{ }^{\mathrm{T} 2} \mathrm{O}_{10}(\mathrm{OH})_{2}$. The methods applied to parameterize the mixing properties of the model were: calorimetry, analysis of existing phase-equilibrium data, line-broadening in powder absorption infrared (IR) spectra, and density functional theory (DFT) calculations. For the calorimetric study, various biotite compositions along the annite-phlogopite, annite-siderophyllite (Sid, K[Al $\left.{ }^{\mathrm{M} 1}[\mathrm{Fe}]_{2}{ }^{\mathrm{M} 2}[\mathrm{Al}]_{2}{ }^{\mathrm{T} 1}[\mathrm{Si}]_{2}{ }^{\mathrm{T} 2} \mathrm{O}_{10}(\mathrm{OH})_{2}\right)$, and annite-eastonite joins were synthesized hydrothermally at $700{ }^{\circ} \mathrm{C}, 4 \mathrm{kbar}$ and $\operatorname{logf}_{\mathrm{O} 2}$ of around -20.2 , close to the redox conditions of the wüstite-magnetite oxygen buffer at that $P-T$ conditions. The samples were characterised by X-ray powder diffraction (XRPD), energydispersive scanning electron microprobe analysis, powder absorption IR spectroscopy, and optical microscopy. The samples were studied further using relaxation calorimetry to measure their heat capacities $\left(C_{\mathrm{p}}\right)$ at temperatures from 2 to $300 \mathrm{~K}$. The measured $C_{\mathrm{p}} / T$ was then integrated to get the calorimetric (vibrational) entropies of the samples at $298.15 \mathrm{~K}$. These show linear behaviour when plotted as a function of composition for all three binaries. Excess entropies of mixing are thus zero for the important biotite joins. Excess volumes of mixing are also zero within error for the three binaries Phl-Ann, AnnSid, and Ann-Eas. KFMASH biotite, therefore, has excess enthalpies which are independent of pressure and temperature $\left(W^{\mathrm{G}} \mathrm{ij}=W_{\mathrm{ij}}^{\mathrm{H}}\right)$. A least-squares procedure was applied in the thermodynamic analysis of published experimental data on the $\mathrm{Fe}-\mathrm{Mg}$ exchange between biotite and olivine, combined with phase-equilibrium data for phlogopite + quartz stability and experimental data for the Al-saturation level of biotite in the assemblage biotite-sillimanite-sanidine-quartz- $\mathrm{H}_{2} \mathrm{O}$ to constrain enthalpic mixing parameters and to derive enthalpy of formation values for biotite endmembers. For Fe-Mg mixing in biotite, the most important binary, this gave best-fit asymmetric Margules enthalpy parameters of $W^{\mathrm{H}}{ }_{\text {AnnPhl }}=14.3 \pm 3.4 \mathrm{~kJ} / \mathrm{mol}$ and $W_{\text {PhlAnn }}^{\mathrm{H}}=-8.8 \pm 8.0 \mathrm{~kJ} / \mathrm{mol}$ (3-cation basis). The resulting asymmetric molar excess Gibbs free energy $\left(\mathrm{G}_{\mathrm{ex}}\right)$ departs only slightly from ideality and is negative at Fe-rich and positive at Mg-rich compositions. Near-ideal activity-composition relationships are thus indicated for the Ann-Phl binary. The presently used low value of $-2 \mathrm{~kJ} / \mathrm{mol}$ for the enthalpy change of the reaction $2 / 3 \mathrm{Phl}+1 / 3 \mathrm{Ann}=\mathrm{Obi}$ is generally confirmed by DFT calculations that gave $-2 \pm 3 \mathrm{~kJ} / \mathrm{mol}$ for this $\Delta H_{F e-M g \text { order }}$, indicating that $\mathrm{Fe}-\mathrm{Mg}$ ordering in biotite is weak. The large enthalpy change of $\Delta H_{M g-A l d i s o r d e r}=34.5 \mathrm{~kJ} / \mathrm{mol}$ for the disordering of $\mathrm{Mg}$ and $\mathrm{Al}$ on the $\mathrm{M}$ sites in Eas (Dachs and Benisek 2019) is reconfirmed by additional DFT calculations. In combination with $W_{\text {PhlEas }}^{\mathrm{H}}=10 \mathrm{~kJ} / \mathrm{mol}$, which is the preferred value of this study describing mixing along the Phl-Eas join, $\mathrm{Mg}-\mathrm{Al}$ disordering over the $\mathrm{M}$ sites of biotite is predicted to be only significant at high temperatures $>1000{ }^{\circ} \mathrm{C}$. In contrast, it plays no role in metamorphic $P-T$ settings.
\end{abstract}

Communicated by Mark S Ghiorso.

Extended author information available on the last page of the article 
Keywords Calorimetry $\cdot$ Heat capacity $\cdot$ KFMASH biotite $\cdot$ Activity model $\cdot$ Thermodynamic mixing properties $\cdot$ Entropy $\cdot$ Molar volume $\cdot$ Annite $\cdot$ Phlogopite

\section{Introduction}

Numerous papers appeared in the literature dealing with the mixing properties of biotite. For the sake of brevity, all this work is not discussed here in detail, but a chronological list of relevant papers is given in supplementary Table S1. In general, either natural $\mathrm{Fe}-\mathrm{Mg}$ distribution coefficients $\left(\mathrm{K}_{\mathrm{D}}\right)$ between biotite and another $\mathrm{Fe}-\mathrm{Mg}$ silicate (mostly garnet), or experimentally determined $\mathrm{K}_{\mathrm{D}} \mathrm{S}$ were used to constrain biotite's $\mathrm{Fe}-\mathrm{Mg}$ mixing properties. To extract these properties from empirical and/or experimental calibrations, the mixing properties of the exchange partner of biotite were required. This is a major problem in all these attempts, as the results become dependent on the choice of solution model and the adopted size of mixing parameters of the exchange partner. As a consequence, all types of $\mathrm{Fe}-\mathrm{Mg}$ mixing behaviour have been proposed, from ideal (Müller 1972; Wones 1972; Ferry and Spear 1978; Schulien 1980; Perchuk and Lavrent'eva 1983; Indares and Martignole 1985; McMullin et al. 1991; Hoisch 1991) to strongly negative (Wones and Eugster 1965) to strongly positive deviation from ideality (Holdaway et al. 1997). Several efforts have also been made to take the effect of $\mathrm{Al}^{\mathrm{VI}}, \mathrm{Fe}^{3+}$, and $\mathrm{Ti}$ in biotite into account (Indares and Martignole 1985; Kleemann and Reinhardt 1994; White et al. 2000, 2014a, 2007; Tajčmanová et al. 2009). The symmetric Margules parameter describing $\mathrm{Fe}-\mathrm{Mg}$ mixing in biotite in the most recent works was approximated as $W^{\mathrm{G}}{ }_{\mathrm{AnnPhl}}=12 \mathrm{~kJ} / \mathrm{mol}$ (3-cation basis) giving a moderate positive deviation from ideality (Holland and Powell 2006; White et al. 2014a). The reasoning behind this is the assumption that $\mathrm{Fe}-\mathrm{Mg}$ mixing in biotite resembles that in olivine, where it is relatively well established from experimental phase-equilibrium, as well as calorimetric work, that the Margules parameter for symmetrical mixing along the fayalite $(\mathrm{Fa})$-forsterite (Fo) join, $W_{\text {FaFo }}^{\mathrm{G}}$, is around $4 \mathrm{~kJ} / \mathrm{mol}$ per octahedral site
(Davidson and Mukhopadhyay 1984; Wiser and Wood 1991; Kojitani and Akaogi 1994; Berman and Aranovich 1996). On the microscopic level, the underlying hypothesis $\left(w_{\text {FeMg,one-oct-site }}\right)^{\mathrm{Fe}-\mathrm{Mg} \text {-silicate }}=\left(w_{\text {FeMg,one-oct-site }}\right)^{\text {olivine }}=4 \mathrm{~kJ} /$ mol results from the heuristic approach of Powell et al. (2014), used to describe $\mathrm{Fe}-\mathrm{Mg}$ mixing, including $\mathrm{Fe}-\mathrm{Mg}$ ordering (see below), in various classes of silicates in cases where experimental data are insufficient or missing, e.g., (White et al. 2014a, b).

With regard to mixing towards the $\mathrm{Al}^{\mathrm{VI}}$-bearing endmembers Eas and Sid (Table 1), the only safe ground to stand upon concerning enthalpic mixing behaviour is the solution calorimetric data of Circone and Navrotsky (1992). These indicate a positive $\Delta H_{\mathrm{ex}}$ for the Phl-Eas join and values of $22.8 \pm 18.7 \mathrm{~kJ} / \mathrm{mol}$ for the enthalpic Margules parameter $W_{\text {PhlEas }}^{\mathrm{H}}$. Dachs and Benisek (2019) studied synthetic members of this join with relaxation calorimetry and XRPD. They found ideal entropic and volumetric mixing behaviour, determined revised thermodynamic standard state data for $\mathrm{Phl}$ and Eas, and derived an enthalpy change $\Delta H_{M g-A l \text { disorder }}=34.5 \pm 3 \mathrm{~kJ} / \mathrm{mol}$ for the disordering of $\mathrm{Al}$ on the M sites in ordered Eas from DFT calculations.

In the KFMASH system, Berman et al. (2007) provided reversed-phase-equilibrium constraints on the stability of $\mathrm{Mg}-\mathrm{Fe}-\mathrm{Al}$ biotite by experimentally determining the $\mathrm{Al}$ saturation level of biotite in the assemblage biotite-sillimanite-sanidine-quartz- $\mathrm{H}_{2} \mathrm{O}$. The $\Delta H_{\mathrm{f}, \mathrm{Ann}}^{\mathrm{o}}$ value, derived from that experiments, is around $15 \mathrm{~kJ} / \mathrm{mol}$ more negative than the one extracted by Dachs and Benisek (2015) from (redox-) equilibria in the FASH system $\left(\Delta H_{\mathrm{f}, \mathrm{Ann}}^{\mathrm{o}}=-5132.5 \pm 2.0 \mathrm{~kJ} /\right.$ $\mathrm{mol})$, which is based on the calorimetrically measured entropy of annite of $S^{\circ}=422.9 \pm 2.9 \mathrm{~J} /(\mathrm{mol} \cdot \mathrm{K})$. The thermodynamic analysis of Berman et al. (2007) resulted in symmetric biotite mixing properties with moderate positive deviation from ideality for $\mathrm{Fe}-\mathrm{Mg}$ and negative deviation for Fe-Al mixing ( $\left.W^{\mathrm{G}}{ }_{\mathrm{AnnSid}}=-8.2 \mathrm{~kJ} / \mathrm{mol}\right)$. An even more
Table 1 Endmembers and site distributions for $\mathrm{Fe}-\mathrm{Mg}-\mathrm{Al}$ biotite

\begin{tabular}{llllll}
\hline & Endmember & Formula & \multicolumn{2}{l}{ Site distribution } \\
\cline { 3 - 5 } \cline { 4 - 5 } & & & $1 \mathrm{M} 1$ & $2 \mathrm{M} 2$ & $2 \mathrm{~T} 1$ \\
\hline 1 & $\mathrm{Phl}$ & $\mathrm{KMg}_{3}\left[(\mathrm{OH})_{2}\left(\mathrm{AlSi}_{3}\right) \mathrm{O}_{10}\right]$ & $\mathrm{Mg}$ & $\mathrm{MgMg}$ & $\mathrm{AlSi}$ \\
2 & Easd (disordered) & $\mathrm{K}\left(\mathrm{AlMg}_{2}\right)\left[(\mathrm{OH})_{2}\left(\mathrm{Al}_{2} \mathrm{Si}_{2}\right) \mathrm{O}_{10}\right]$ & $\mathrm{Al}_{1 / 3} \mathrm{Mg}_{2 / 3}$ & $\mathrm{Al}_{2 / 3} \mathrm{Mg}_{4 / 3}$ & $\mathrm{AlAl}$ \\
3 & Eas (ordered) & $\mathrm{K}\left(\mathrm{AlMg}_{2}\right)\left[(\mathrm{OH})_{2}\left(\mathrm{Al}_{2} \mathrm{Si}_{2}\right) \mathrm{O}_{10}\right]$ & $\mathrm{Al}$ & $\mathrm{MgMg}$ & $\mathrm{AlAl}$ \\
4 & Ann & $\mathrm{KFe}_{3}\left[(\mathrm{OH})_{2}\left(\mathrm{AlSi}_{3}\right) \mathrm{O}_{10}\right]$ & $\mathrm{Fe}$ & $\mathrm{FeFe}$ & $\mathrm{AlSi}$ \\
5 & Obi (ordered) & $\mathrm{K}\left(\mathrm{FeMg}_{2}\right)\left[(\mathrm{OH})_{2}\left(\mathrm{AlSi}_{3}\right) \mathrm{O}_{10}\right]$ & $\mathrm{Fe}$ & $\mathrm{MgMg}$ & $\mathrm{AlSi}$ \\
6 & Sid (dependent) & $\mathrm{K}\left(\mathrm{AlFe}_{2}\right)\left[(\mathrm{OH})_{2}\left(\mathrm{Al}_{2} \mathrm{Si}_{2}\right) \mathrm{O}_{10}\right]$ & $\mathrm{Al}$ & $\mathrm{FeFe}$ & $\mathrm{AlAl}$ \\
\hline
\end{tabular}


negative $W^{\mathrm{G}}$ AnnSid was proposed earlier by Benisek et al. (1999) for the Ann-Sid join ( $W^{\mathrm{G}}$ AnnSid $\left.=-29 \mathrm{~kJ} / \mathrm{mol}\right)$. These assertions of negative $W^{\mathrm{G}}$ 's for the Ann-Sid join conflict with positive ones in the order of $7 \mathrm{~kJ} / \mathrm{mol}$ as used in recent biotite activity models (Holland and Powell 2006; White et al. 2014a).

Noting that equipartitioning of $\mathrm{Fe}$ and $\mathrm{Mg}$ on octahedral sites of biotite, as assumed in all earlier work prior to ca. the year 2000, leads to inconsistencies with regard to the formulation of ideal activities, $\mathrm{Fe}-\mathrm{Mg}$ ordering was introduced based on the ordering reaction $2 / 3 \mathrm{Phl}+1 / 3 \mathrm{Ann}=\mathrm{Obi}$ (Powell and Holland 1999). By assuming various values for the order parameter $Q \equiv X_{\mathrm{Fe}}{ }^{\mathrm{M} 1}-X_{\mathrm{Fe}}^{\mathrm{M} 2}$ (where $X_{\mathrm{Fe}}{ }^{\mathrm{M} 1}, X_{\mathrm{Fe}}{ }^{\mathrm{M} 2}$ are the site fractions of $\mathrm{Fe}$ on the M1 or M2 site of biotite,

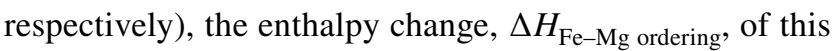
$\mathrm{Fe}-\mathrm{Mg}$ ordering reaction was initially constrained to a value of $-10.75 \mathrm{~kJ} / \mathrm{mol}$ (Powell and Holland 1999) producing a rather pronounced $\mathrm{Fe}-\mathrm{Mg}$ ordering. It was later changed to $-2 \mathrm{~kJ} / \mathrm{mol}$ (Holland and Powell 2006), thereby reducing the degree of $\mathrm{Fe}-\mathrm{Mg}$ ordering, and approximated as $-6.8 \mathrm{~kJ} /$ mol by Tajčmanova et al. (2009) to improve the match of model-predicted octahedral $\mathrm{Al}$ contents in biotite $\left(\mathrm{Al}^{\mathrm{VI}}\right)$ with natural observations.

The aim of the present contribution is:

1. To determine, using well-characterised synthetic samples, entropic and volumetric mixing properties of the important biotite binaries Ann-Phl, Ann-Sid, and AnnEas via relaxation calorimetry and XRPD,

2. to derive enthalpic mixing properties of biotite binaries from the experimental data of Zhou (1994) and Berman et al. (2007), in combination with the evaluation of line broadening in powder absorption IR spectra,

3 . to constrain values for the enthalpy change of the ordering reaction 2/3 $\mathrm{Phl}+1 / 3 \mathrm{Ann}=$ Obi from DFT calculations.

The impact of this biotite activity model on phase relations in the KFMASH system is presented in the companion paper.

\section{Methods}

\section{Sample synthesis and characterisation}

Samples along the Ann-Phl and Ann-Eas binaries were synthesized from gels in a conventional cold-seal hydrothermal apparatus at a temperature of $700{ }^{\circ} \mathrm{C}$ and a pressure of 4 kbar. Run durations were about 3 weeks. Details of the hydrothermal apparatus, the applied gel method, and chemicals used in the gel preparation can be found in Dachs (1994) and will not be repeated here.
Redox conditions during synthesis were at a $\log \mathrm{f}_{\mathrm{O} 2}$ of around -20.2 as measured by hydrogen sensors, close to that of the wüstite-magnetite oxygen buffer at these $P-T$ conditions. Using Mössbauer spectroscopy, Dachs and Benisek (2015) demonstrated that such conditions are sufficiently reducing to keep the $\mathrm{Fe}^{3+}$ content of annite at its well-known minimum of $10 \pm 2 \%$ (Hazen and Wones 1972; Redhammer et al. 1993). For the synthetic Ann-Phl biotites, we thus corrected our mineral chemistries by taking $10 \%$ of $\mathrm{Fe}^{\text {tot }}$ as $\mathrm{Fe}^{3+}$ at the Fe-rich side of the binary and decreasing it linearly to $0 \%$ towards Phl (Redhammer et al. 1995). For simplicity, we assume that this amount of $\mathrm{Fe}^{3+}$ is incorporated by a vacancy $(\square)$ mechanism, i.e., $3 \mathrm{Fe}^{2+}(\mathrm{oct})=2$ $\mathrm{Fe}^{3+}$ (oct) $+\square$ (oct), e.g., (Redhammer et al. 1993). This requires a ferric iron-rich vacancy $(\square)$ endmember, $\mathrm{K}[\square]^{\mathrm{M} 1}\left[\mathrm{Fe}^{3+}\right]_{2}^{\mathrm{M} 2}\left[\mathrm{Al}_{0.5} \mathrm{Si}_{0.5}\right]_{2}^{\mathrm{T} 1}\left[\mathrm{Si}_{2}{ }^{\mathrm{T} 2} \mathrm{O}_{10}(\mathrm{OH})_{2}\right.$ besides Ann and $\mathrm{Phl}$ as the third component to compositionally describe our synthetic Fe-Mg biotites. The samples calorimetrically studied will be subsequently referred to as, e.g., Ann50Phl50 for $\mathrm{K}\left(\mathrm{Fe}_{1.5} \mathrm{Mg}_{1.5}\right)\left[\mathrm{AlSi}_{3} \mathrm{O}_{10}(\mathrm{OH})_{2}\right]$.

Synthesis products were examined by optical microscopy and by XRPD using a Bruker D8 Advance X-ray diffractometer to check phase purity. Their chemical compositions were determined using an energy-dispersive scanning electron microscope (type: Zeiss Ultra Plus 55 equipped with an Oxford Instrument $50 \mathrm{~mm}^{2}$ SDD EDX detector). Powders were pressed into pellets for this purpose.

Lattice constants were calculated from XRPD patterns collected on a Siemend D-500 diffractometer between $5^{\circ}$ and $110^{\circ} 2 \theta\left(\mathrm{Cu}-\mathrm{K}_{\alpha}\right.$ radiation) using the software UnitCell (Holland and Redfern 1997). The lattice constants determined in this way were validated by checking them against a Rietveld refinement, which was done using the software Fullprof (Rodriguez-Carvajal 2001) of the sample Phl60Eas40.

Powder absorption IR spectra were recorded on a Bruker IFS66v/S spectrometer in the wave number region $175-1300 \mathrm{~cm}^{-1}$ using polyethylene and $\mathrm{KBr}$ pellets for the low and high wavenumber regions, respectively, to investigate the line broadening as a result of forming the biotite solid solutions (Boffa Ballaran et al. 1999; Salje et al. 2000; Boffa Ballaran 2003). For that purpose, selected absorption peaks were subject to an autocorrelation analysis, using a self-written Mathematica program, from which $\Delta$ corr and $\delta \Delta$ corr values were obtained, which are the parameters describing the broadening of the powder absorption IR spectra of the solid solutions relative to the powder absorption IR spectra of the endmembers. The latter were then transformed into excess enthalpies of mixing, $\Delta H_{\mathrm{ex}}$, based on the empirical mixing enthalpy-IR line-broadening correlation derived by Etzel and Benisek (2008): $\Delta H_{\mathrm{ex}}{ }^{\Delta \text { corr }}=\left(d+k \cdot n o r m V^{\mathrm{exc}}{ }_{\text {int }}\right) \cdot \delta \Delta$ corr $\cdot n$, where $n=$ number of atoms per formula unit, $d=13.0 / 10.5 \mathrm{~J} \cdot \mathrm{cm} \cdot \mathrm{mol}^{-1}$ for the middle/high-wave number regions and $k=308 \mathrm{~J} \cdot \mathrm{cm}^{-2}$ and 
norm $V_{\text {int }}^{\text {exc }}$ is the integrated excess volume of mixing normalised to one atom per formula unit. Etzel and Benisek (2008) established their correlation between $\delta \Delta$ corr and $\Delta H^{\text {mix }}$ using data from six binaries. In the meantime, their approach has been applied to other binaries, as well, i.e., ternary feldspars (Benisek et al. 2010), low structural state plagioclases (Benisek et al. 2013), grossular-spessartine binary (Dachs et al. 2014a), almandine-spessartine binary (Dachs et al. 2014b), and the $\mathrm{Mg}-\mathrm{Al}$ biotite solid solution (Dachs and Benisek, 2019). As shown by Tarantino et al. (2003), the overlap of $\delta \Delta$ corr and calorimetrically measured $\Delta H^{\text {mix }}$ for the olivine solid solution is remarkable. This correlation was thought to give wrong results for the glaucophane-tremolite solid solution (Jenkins et al. 2014). However, as shown by Benisek and Dachs (2020), if this method is correctly applied, the results agree with the derived $\Delta H^{\text {mix }}$ values of Jenkins et al (2014). The method using $\delta \Delta$ corr to extract $\Delta H^{\mathrm{mix}}$ has, however, problems for some binaries, as different IR wave number regions yield different $\Delta H^{\text {mix }}$ values. However, if the appropriate wave number region is selected, which is indicative of local heterogeneities caused by the substitution and where peak shifts are not a dominant feature (Tarantino et al. 2003), it seems to be a promising tool for determining the heat of mixing or ordering.

\section{Calorimetric methods and data evaluation}

Low-temperature heat capacities were measured using a commercially available relaxation calorimeter (the heat capacity option of the Quantum Design ${ }^{\circledR}$ Physical properties measurement system-PPMS). The data were collected in triplicate at 60 different temperatures between 2 and $300 \mathrm{~K}$, using a logarithmic spacing resulting in a higher data density at a lower temperature. The samples consisted of $12-15 \mathrm{mg}$ of crystallites wrapped in thin $\mathrm{Al}$ foil and compressed to a $\sim 0.5 \mathrm{~mm}$-thick pellet that was then attached to the sample platform of the calorimeter with Apiezon $\mathrm{N}$-grease, to facilitate the required thermal contact.

Further details on the calorimetric technique and measuring procedures have already been described several times and will not be repeated here (Lashley et al. 2003; Dachs and Bertoldi 2005; Kennedy et al. 2007; Dachs and Benisek 2011). All calorimetric data are given in Supplementary Table S2.

The calorimetric (vibrational) molar entropy $\left(S_{\text {cal }}\right)$ of each compound at $298.15 \mathrm{~K}$ was calculated by solving the integral:

$S_{c a l}=S^{T=298.15 K}-S^{T=0 K}=\int_{0}^{298.15} \frac{C_{P}}{T} d T$.
$S_{\text {cal }}$ corresponds to the standard state (third-law) entropy, $S^{\mathrm{o}}$, in the case of an ordered endmember (which assumes $S^{T=0 \mathrm{~K}}=0$ ). Errors in $S_{\text {cal }}$ were estimated according to Dachs and Benisek (2011). The entropy increment $0-2 \mathrm{~K}$, not covered by measured $C_{\mathrm{p}}$ data, is negligible for $\mathrm{Mg}$-rich samples, because absolute $C_{\mathrm{p}}$ values are so small, so that this increment affects $S_{\text {cal }}$ only at the second decimal place. The lowermost $C_{\mathrm{p}}$ values of Fe-rich samples from the range $2-5 \mathrm{~K}$, on the other hand, were fitted to the equation $C_{\mathrm{p}}=\mathrm{a} \cdot \mathrm{T}^{3}+\mathrm{b} \cdot \mathrm{T}^{5}$, from which the entropy increment $0-2 \mathrm{~K}$ was computed and added to $S_{\text {cal }}$. It amounted to $0.2 \mathrm{~J} /(\mathrm{mol} \cdot \mathrm{K})$ at maximum.

\section{Computational methods}

Quantum-mechanical calculations were based on the DFT plane-wave pseudopotential approach implemented in the CASTEP code (Clark et al. 2005) included in the Materials Studio software from Biovia ${ }^{\circledR}$. The calculations used the local density approximation (LDA) for the exchange-correlation functional (Ceperley and Alder 1980). To describe the core-valence interactions, ultrasoft pseudopotentials were used with the $1 \mathrm{~s}^{1}, 2 \mathrm{~s}^{2} 2 \mathrm{p}^{4}, 2 \mathrm{p}^{6} 3 \mathrm{~s}^{2}, 3 \mathrm{~s}^{2} 3 \mathrm{pPhl}, 3 \mathrm{~s}^{2} 3 \mathrm{p}^{2}$, $3 s^{2} 3 p^{6} 4 s^{1}$, and $3 d^{6} 4 s^{2}$ electrons explicitly treated as valence electrons for $\mathrm{H}, \mathrm{O}, \mathrm{Mg}, \mathrm{Al}, \mathrm{Si}, \mathrm{K}$, and $\mathrm{Fe}$, respectively. The calculations on Fe-containing minerals used the $L D A+U$ approach (Zhou et al. 2004), with $U=2.0-3.0 \mathrm{eV}$ applied to the $\mathrm{d}$ orbitals of $\mathrm{Fe}$ ). The k-point sampling used a Monkhorst-Pack grid (Monkhorst and Pack 1976) with a spacing of $0.02 \AA^{-1}$ for the energy calculations. Convergence was tested by performing calculations using a denser k-point grid. The structural relaxation was calculated by applying the BFGS algorithm (Pfrommer et al. 1997), where the maximum force on the atom was within $0.01 \mathrm{eV} / \mathrm{A}$. The enthalpy of mixing was simulated by the single defect method (Sluiter and Kawazoe 2002), which investigates supercells with almost endmember composition having only a single substitutional defect. The energy calculations of the endmembers and such supercells provide the interaction parameters, because the results can easily be transformed into the slopes of the heat of mixing function ( $\mathrm{Li}$ et al. 2014). The simulations concerning the enthalpies of ordering/disordering used the same computational methods as described in Dachs and Benisek (2019). The transformation of CASTEP energies (in $\mathrm{eV}$ ) into enthalpies (in $\mathrm{kJ} / \mathrm{mol}$ ) was done as outlined in Benisek and Dachs $(2018,2020)$.

\section{Results}

\section{A new activity model for Fe-Mg-Al biotites}

In the following, we present a new activity model for biotite that is an extension of the model of Dachs and Benisek 
(2019) for $\mathrm{Mg}-\mathrm{Al}$ biotite by introducing the Fe-bearing endmembers Ann and ordered Fe-Mg biotite (Obi). This model for the KFMASH system considers 5 linearly independent endmembers, as shown in Table 1, and includes Fe-Mg and $\mathrm{Mg}-\mathrm{Al}$ order-disorder.

Using a Margules-type expression for its molar excess Gibbs free energy, $\mathrm{G}_{\mathrm{ex}}$, as originally formulated by Wohl (1946, 1953) and expanded to multicomponent solutions by Jackson (1989), the resulting $G_{\mathrm{ex}}$ expression for the new biotite solution model is:

$G_{e x}=p_{\text {Phl }} p_{\text {Easd }} W_{\text {PhlEasd }}^{G}\left(p_{\text {Phl }}+p_{\text {Easd }}\right)+p_{\text {Phl }} p_{\text {Eas }} W_{\text {PhlEas }}^{G}\left(p_{\text {Phl }}+p_{\text {Eas }}\right)$ $+p_{\text {Phl }} p_{\text {Ann }}\left(p_{\text {Ann }} W_{P h l A n n}^{G}+p_{P h l} W_{\text {AnnPhl }}^{G}\right)+p_{\text {Phl }} p_{\text {Obi }} W_{P h l O b i}^{G}\left(p_{P h l}+p_{\text {Obi }}\right)$ $+p_{\text {Easd }} p_{\text {Eas }} W_{\text {EasdEas }}^{G}\left(p_{\text {Easd }}+p_{\text {Eas }}\right)+p_{\text {Easd }} p_{\text {Ann }} W_{\text {EasdAnn }}^{G}\left(p_{\text {Easd }}+p_{\text {Ann }}\right)$ $+p_{\text {Easd }} p_{\text {Obi }} W_{\text {EasdObi }}^{G}\left(p_{\text {Easd }}+p_{\text {Obi }}\right)+p_{\text {Eas }} p_{\text {Ann }} W_{\text {EasAnn }}^{G}\left(p_{\text {Eas }}+p_{\text {Ann }}\right)$

$+p_{\text {Eas }} p_{\text {Obi }} W_{\text {EasObi }}^{G}\left(p_{\text {Eas }}+p_{\text {Obi }}\right)+p_{\text {Ann }} p_{\text {Obi }} W_{\text {AnnObi }}^{G}\left(p_{\text {Ann }}+p_{O b i}\right)$

$+p_{\text {Phl }} p_{\text {Easd }} p_{\text {Eas }} Q_{\text {PhlEasdEas }}+p_{\text {Phl }} p_{\text {Easd }} p_{\text {Ann }} Q_{\text {PhlEasdAnn }}$

$+p_{\text {Phl }} p_{\text {Easd }} p_{\text {Obi }} Q_{\text {PhlEasdObi }}+p_{\text {Phl }} p_{\text {Eas }} p_{\text {Ann }} Q_{\text {PhlEasAnn }}$

$+p_{\text {Phl }} p_{\text {Eas }} p_{\text {Obi }} Q_{\text {PhlEas Obi }}+p_{P h l} p_{\text {Ann }} p_{\text {Obi }} Q_{\text {PhlAnnObi }}$

$+p_{\text {Easd }} p_{\text {Eas }} p_{\text {Ann }} Q_{\text {EasdEasAnn }}+p_{\text {Easd }} p_{\text {Eas }} p_{\text {Obi }} Q_{\text {EasdEas } O b i}$

$+p_{\text {Easd }} p_{\text {Ann }} p_{\text {Obi }} Q_{\text {EasdAnnObi }}+p_{\text {Eas }} p_{\text {Ann }} p_{\text {Obi }} Q_{\text {EasAnnObi }}$,

where each interaction parameter, $W_{i j}^{G}$, is given by:

$W_{i j}^{G}=W_{i j}^{H}-T W_{i j}^{S}+P W_{i j}^{V}$.

The $p_{\mathrm{i}}$ 's are the molar proportions of the endmembers and the $Q_{\mathrm{ijk}}$ 's are defined as:

$Q_{i j k}=(1 / 2)\left[\left(W_{i j}^{G}+W_{j i}^{G}+W_{i k}^{G}+W_{k i}^{G}+W_{j k}^{G}+W_{k j}^{G}\right)-C_{i j k}\right]$

(e.g., Jackson 1989, his Eq. 3). The $C_{\mathrm{ijk}} \mathrm{s}$ are the ternary constants (set to zero due to the absence of appropriate data to calibrate them). Note that each biotite binary is treated as a symmetric solution (i.e., $\mathrm{W}_{\mathrm{ij}}=\mathrm{W}_{\mathrm{ji}}$ ), except the Phl-Ann join with the two interaction parameters $\mathrm{W}_{\text {Phlann }}^{\mathrm{G}}$ and $\mathrm{W}^{\mathrm{G}}{ }_{\text {AnnPhl }}$ (the reason for that is discussed below).

Based on Eq. (2), the activity coefficient, $\gamma_{\mathrm{i}}$, of, e.g., the Phl component is then given by (Jackson 1989, his Eq. 7):

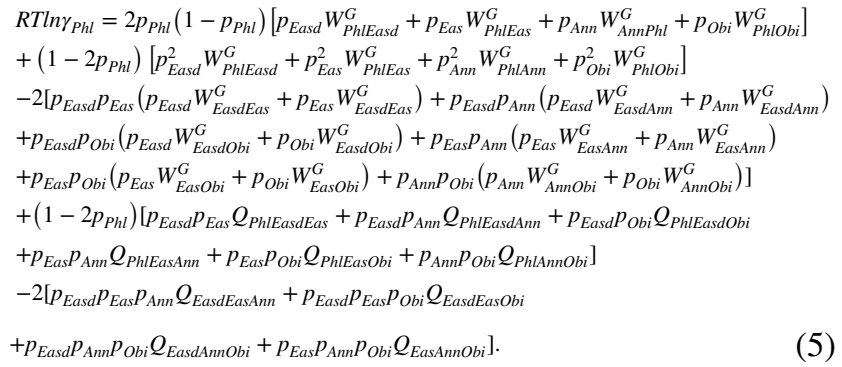

The RTln $\gamma$ expressions for the other biotite endmembers can be found by appropriate rotations of subscripts, so for RTln $\gamma_{\text {Easd }}:$ Phl $\rightarrow$ Easd, Easd $\rightarrow$ Eas, Eas $\rightarrow$ Ann, Ann $\rightarrow$ Obi, $\mathrm{Obi} \rightarrow \mathrm{Phl}$; for RTln $\gamma_{\text {Eas }}: \mathrm{Phl} \rightarrow$ Eas, Easd $\rightarrow$ Ann, Eas $\rightarrow$ Obi, Ann $\rightarrow$ Phl, Obi $\rightarrow$ Easd; for $R T \ln \gamma_{\text {Ann }}:$ Phl $\rightarrow$ Ann, Easd $\rightarrow$ Obi, Eas $\rightarrow$ Phl, Ann $\rightarrow$ Easd, Obi $\rightarrow$ Eas; for RTln $\gamma_{\text {Obi }}:$ Phl $\rightarrow$ Obi, Easd $\rightarrow$ Phl, Eas $\rightarrow$ Easd, Ann $\rightarrow$ Eas, Obi $\rightarrow$ Ann.

Ideal mixing on site activities, $a_{\mathrm{i}}^{\mathrm{id}}$, of the biotite endmembers are:

$$
\begin{aligned}
& a_{P h l}^{i d}=4 X_{M g}^{M 1}\left(X_{M g}^{M 2}\right)^{2} X_{S i}^{T 1} X_{A l}^{T 1}, \\
& a_{E a s d}^{i d}=(27 / 4)\left(X_{M g}^{M 1}\right)^{\frac{2}{3}}\left(X_{A l}^{M 1}\right)^{\frac{1}{3}}\left(X_{M g}^{M 2}\right)^{\frac{4}{3}}\left(X_{A l}^{M 2}\right)^{\frac{2}{3}}\left(X_{A l}^{T 1}\right)^{2}, \\
& a_{E a s}^{i d}=X_{A l}^{M 1}\left(X_{M g}^{M 2}\right)^{2}\left(X_{A l}^{T 1}\right)^{2}, \\
& a_{A n n}^{i d}=4 X_{F e}^{M 1}\left(X_{F e}^{M 2}\right)^{2} X_{S i}^{T 1} X_{A l}^{T 1}, \\
& a_{O b i}^{i d}=4 X_{F e}^{M 1}\left(X_{M g}^{M 2}\right)^{2} X_{A l}^{T 1} X_{S i}^{T 1} .
\end{aligned}
$$

The site fractions, $X_{i}^{\mathrm{j}}$, expressed in terms of proportions of the five linearly independent endmembers are given by:

$X_{M g}^{M 1}=p_{P h l}+(2 / 3) p_{E a s d}, X_{F e}^{M 1}=p_{A n n}+p_{O b i}, X_{A l}^{M 1}=p_{E a s}+(1 / 3) p_{E a s d}$,

$X_{M g}^{M 2}=1-p_{A n n}-(1 / 3) p_{E a s d}, X_{F e}^{M 2}=p_{A n n}, X_{A l}^{M 2}=(1 / 3) p_{\text {Easd }}$,

$X_{A l}^{T 1}=1-\left(p_{P h l}+p_{A n n}+p_{O b i}\right) / 2, X_{S i}^{T 1}=\left(p_{P h l}+p_{A n n}+p_{O b i}\right) / 2$.

The disordering of $\mathrm{Mg}$ and $\mathrm{Al}$ on the $\mathrm{M}$ sites of Eas is modelled via the equilibrium (Dachs and Benisek 2019):

ordered - Eastonitedisordered - Eastonite

$$
\begin{aligned}
& \mathrm{K}[\mathrm{Al}]^{\mathrm{M} 1}[\mathrm{Mg}]_{2}^{\mathrm{M} 2}[\mathrm{Al}]_{2}^{\mathrm{T} 1}[\mathrm{Si}]_{2}^{\mathrm{T} 2} \mathrm{O}_{10}(\mathrm{OH})_{2} \\
& =\mathrm{K}\left[\mathrm{Al}_{1 / 3} \mathrm{Mg}_{2 / 3}\right]^{\mathrm{M} 1}\left[\mathrm{Al}_{1 / 3} \mathrm{Mg}_{2 / 3}\right]_{2}^{\mathrm{M} 2}[\mathrm{Al}]_{2}^{\mathrm{T} 1}[\mathrm{Si}]_{2}^{\mathrm{T} 2} \mathrm{O}_{10}(\mathrm{OH})_{2}
\end{aligned}
$$

These authors derived an enthalpy of disordering of $\Delta H_{(\text {eq. } 8)}=34.5 \pm 3 \mathrm{~kJ} / \mathrm{mol}$ from DFT calculations.

To describe $\mathrm{Fe}-\mathrm{Mg}$ ordering in biotite, we follow Powell and Holland (1999), Holland and Powell (2006) using the internal reaction:

$\frac{2}{3}$ Phlogopite $+\frac{1}{3}$ Annite $=$ ordered $\mathrm{Fe}-$ Mg biotite .

Later, modifications and extensions of this KFMASH biotite activity model (White et al. 2000, 2007, 2014a; Tajčmanová et al. 2009; Powell et al. 2014) are all formulated on the basis of reaction (9) to model Fe-Mg order-disorder. To get a value for the corresponding enthalpy, $\Delta H_{(\text {eq. } 9)}$, we computed CASTEP energies for Ann, Phl, and Obi. From these energies (Table 2), $\Delta H_{\text {(eq. 9) }}$ was then calculated by 
simply subtracting the energy of a mechanical mixture of 2/3 Phl $+1 / 3$ Ann from that of Obi. The CASTEP results for the two Fe-bearing endmembers depend on the value of $U$ in $L D A+U$ calculations. For its default value of $2.5 \mathrm{eV}$ in CASTEP, we obtain $\Delta H_{\text {(eq. 9) }}=-2.1 \mathrm{~kJ} / \mathrm{mol}$. To see the effect of changing $U$ on the resulting $\Delta H_{\text {(eq. 9), we have }}$ repeated the above computations with values of 2.0 and $3.0 \mathrm{eV}$ for $U$ (Table 2). The dependence of $\Delta H_{\text {(eq. 9) }}$ on predefined $U$ is moderate, giving a range of reasonable $\Delta H_{\text {(eq. 9) }}$ values of +2.5 to $-5.2 \mathrm{~kJ} / \mathrm{mol}$ for $U$ 's varying between 2 and $3 \mathrm{eV}$. In all further computations, we use a value in the middle of this range, i.e., $\Delta H_{\text {(eq. 9) }}=-2.0 \mathrm{~kJ} / \mathrm{mol}$.

Following Tajčmanova et al. (2009), (Appendix), the $p_{\mathrm{i}} \mathrm{s}$, representing the stable speciation, can be written as function of the bulk composition parameters by defining proportions $p_{i}^{0}$ for the fully disordered state and taking into account the stoichiometric constraints imposed by ordering reactions (8) and (9):

$$
\begin{aligned}
& p_{P h l}=p_{P h l}^{0}-(2 / 3) \delta p_{O b i}, \\
& p_{E a s d}=p_{E a s d}^{0}-\delta p_{E a s}, \\
& p_{E a s}=p_{E a s}^{0}+\delta p_{E a s}, \\
& p_{A n n}=p_{A n n}^{0}-(1 / 3) \delta p_{O b i}, \\
& p_{O b i}=p_{O b i}^{0}+\delta p_{O b i} .
\end{aligned}
$$

The unknown quantities $\delta p_{\text {Eas }}$ and $\delta p_{\mathrm{Obi}}$ are fractional amounts of the ordered endmembers Eas and Obi, by which the proportions $p_{\mathrm{i}}^{0}$ for the fully disordered state are lowered as result of ordering. The $p_{\mathrm{i}}^{0} \mathrm{~s}$ are related to the bulk parameters $X_{\mathrm{Mg}}=\mathrm{Mg} /\left(\mathrm{Mg}+\mathrm{Fe}^{2+}\right)$ and $\mathrm{Al}^{\mathrm{VI}}=$ octahedral $\mathrm{Al}$ via:

Table 2 CASTEP energies $\left(\Delta U^{0 \mathrm{~K}}\right)$ for Phl, Ann, and Obi calculated using ultrasoft pseudopotentials

\begin{tabular}{llll}
\hline $\mathrm{U}$ & $\Delta U^{0 \mathrm{~K}}$ & $\Delta U^{0 \mathrm{~K}}$ & $\Delta U^{0 \mathrm{~K}}$ \\
& $\mathrm{~kJ} / \mathrm{mol}$ & $\mathrm{kJ} / \mathrm{mol}$ & $\mathrm{kJ} / \mathrm{mol}$ \\
& 2.0 & 2.5 & 3.0 \\
\hline Phl & $-905,636.11$ & $-905,636.11$ & $-905,636.11$ \\
Ann & $-871,262.51$ & $-871,212.13$ & $-871,167.71$ \\
Obi & $-894,175.80$ & $-894,163.58$ & $-894,151.87$ \\
$\Delta H_{(\text {eq. } 9)} \mathrm{kJ} / \mathrm{mol}$ & 2.45 & -2.13 & -5.23 \\
\hline
\end{tabular}

For the Fe-bearing endmembers Ann and Obi, three different values are given, computed with $U=2.0, U=2.5$ (default in CASTEP) and $U=3.0 \mathrm{eV}$. The resulting enthalpy change of the ordering reaction

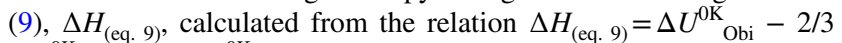
$\Delta U_{\mathrm{Phl}}^{0 \mathrm{~K}}-1 / 3 \Delta U^{0 \mathrm{~K}}{ }_{\mathrm{Ann}}$, is given in the last row
$p_{P h l}^{0}=X_{M g}-(1 / 3)\left(A l^{V I}\left(X_{M g}+2\right)\right)$,

$p_{\text {Easd }}^{0}=A l^{V I}, p_{\text {Eas }}^{0}=0$,

$p_{A n n}^{0}=1-X_{M g}+(1 / 3)\left(A l^{V I}\left(X_{M g}-1\right)\right)$,

$p_{O b i}^{0}=0$.

The equilibrium degree of ordering at given $P$ and $T$ is found by solving $\Delta G=0$ of Eqs. (8) and (9) simultaneously for the two unknowns $\delta p_{\text {Eas }}$ and $\delta p_{\mathrm{Obi}}$ :

$$
\begin{aligned}
\Delta G_{(e q .8)}= & \Delta H_{(e q .8)}-T \Delta S_{(e q .8)}+R T \ln \left(a_{\text {Easd }}^{i d} / a_{E a s}^{i d}\right) \\
& +R T \ln \gamma_{E a s d}-R T \ln \gamma_{E a s} \\
\Delta G_{(e q .9)}= & \Delta H_{(e q .9)}-T \Delta S_{(e q .9)}+R T \ln \left[a_{O b i}^{i d} /\left(\left(a_{P h l}^{i d}\right)^{\frac{2}{3}}\left(a_{A n n}^{i d}\right)^{\frac{1}{3}}\right)\right] \\
& +R T \ln \gamma_{O b i}-(2 / 3) R T \ln \gamma_{P h l}-(1 / 3) R T \ln \gamma_{A n n} .
\end{aligned}
$$

$\Delta S_{\text {(eq. 8) }}$ equals the configurational entropy of Easd $=\mathrm{R} \ln (27 / 4) \mathrm{J} /(\mathrm{mol} \cdot \mathrm{K})$ and $\Delta S_{\text {(eq. 9) }}=0 \mathrm{~J} /(\mathrm{mol} \cdot \mathrm{K})$.

Activities of biotite endmembers are then given by: $a_{\mathrm{i}}=a_{\mathrm{i}}^{\mathrm{id}} \gamma_{\mathrm{i}}$.

\section{Calibrating the mixing parameters and extracting the standard enthalpy of formation values of biotite endmembers}

\section{Excess entropies and volumes of mixing $\left(\Delta S_{\mathrm{ex}}, \Delta V_{\mathrm{ex}}\right)$ of biotite binaries}

Annite-phlogopite Atoms per formula unit (apfu) of the synthesized Ann-Phl solid solutions are given in Table 3. They were computed from the average of at least 5 , but mostly 10-15 separate microprobe analyses. The synthetic $\mathrm{Fe}-\mathrm{Mg}$ biotites appeared as fine-grained aggregates of thin $(<1 \mu)$, often pseudohexagonal platelets not exceeding $10 \mu$ in diameter, with a light-greenish colour that gets more intensive towards Fe-rich compositions. The optical examination and XRPD patterns showed impurities of fayalite and sanidine of $<5 \%$ in only the Fe-rich biotites. Formula units of $\mathrm{Si}$ in all $\mathrm{Fe}-\mathrm{Mg}$ biotites are 3.0 apfu within error, except in $\mathrm{Fe}$ rich ones, where some Tschermak-substituted $\mathrm{Al}$ (and possibly also $\mathrm{Fe}^{3+}$ ) are present (see footnotes to Table 3). This is reflected by the number of endmembers needed to describe the composition of our synthetic Fe-Mg biotites: Ann, Phl, and small amounts of the Vac end member (decreasing from $10 \%$ in Ann90Phl10 to 0\% in Phl100) are sufficient for biotites with $0.3<X_{\mathrm{Mg}}<1$. The additional Tschermak-type endmembers Sid and Eas in the order of total $6 \%, 7 \%$, and $14 \mathrm{~mol} \%$ are required for describing the nominal compositions of Ann80Phl20, Ann90Phl10, and Ann100.

The heat capacities of all $\mathrm{Fe}-\mathrm{Mg}$ biotites synthesized in this study, as well as those of Ann (Dachs and Benisek 2015) 
Table 3 Formula units, mole fractions of biotite endmembers, calorimetric (vibrational) entropies, $S_{\text {cal }}$, at 298.15 (determined from PPMS measurements), excess enthalpies of mixing, $\Delta$ corr and $\Delta H_{\mathrm{ex}}$ values (derived from line broadening in powder absorption IR spectra), and molar volumes, $\mathrm{V}_{\mathrm{o}}$, of members of the Ann-Phl join synthesized in this study

\begin{tabular}{|c|c|c|c|c|c|c|c|c|c|}
\hline & Ann100 ${ }^{1}$ & Ann90Phl10 & Ann80Phl20 & Ann70Phl30 & Ann60Phl40 & Ann50Phl50 & Ann40Phl60 & Ann20Phl80 & Phl100² \\
\hline $\mathrm{Si}$ & $2.86(2)$ & $2.93(4)$ & $2.94(4)$ & $3.03(6)$ & $3.01(6)$ & $3.04(5)$ & $3.05(3)$ & $3.00(4)$ & $3.01(3)$ \\
\hline $\mathrm{Al}$ & $1.13(6)$ & $1.15(3)$ & $1.10(3)$ & $1.08(4)$ & $1.00(4)$ & $1.03(5)$ & 0.99 (2) & $0.99(2)$ & $1.02(3)$ \\
\hline $\mathrm{Fe}^{2+}$ & $2.67(6)$ & $2.28(5)$ & $2.10(4)$ & $1.73(5)$ & $1.56(4)$ & $1.28(5)$ & $1.01(2)$ & $0.52(2)$ & 0 \\
\hline $\mathrm{Fe}^{3+}$ & $0.30(1)$ & $0.20(1)$ & $0.16(1)$ & $0.11(1)$ & $0.10(1)$ & 0.07 (1) & 0.05 (1) & $0.01(1)$ & 0 \\
\hline $\mathrm{Mg}$ & 0 & $0.35(5)$ & $0.66(3)$ & $0.95(5)$ & $1.31(5)$ & $1.50(5)$ & $1.88(4)$ & $2.52(5)$ & $2.99(6)$ \\
\hline K & $0.96(4)$ & $0.95(5)$ & $0.96(2)$ & $0.95(2)$ & $0.92(2)$ & $0.98(3)$ & $0.92(2)$ & $0.94(2)$ & $0.97(5)$ \\
\hline$X_{\text {Ann }}$ & $0.79(2)$ & $0.72(2)$ & $0.65(2)$ & $0.61(2)$ & $0.52(2)$ & $0.44(2)$ & $0.34(2)$ & $0.17(2)$ & 0 \\
\hline$X_{\mathrm{Phl}}$ & $0.00(2)$ & $0.11(1)$ & $0.21(1)$ & $0.33(1)$ & $0.43(1)$ & $0.52(3)$ & $0.63(3)$ & $0.82(3)$ & $1.00(2)$ \\
\hline$X_{\text {Sid }}$ & $0.14(2)^{3}$ & $0.06(3)$ & $0.05(3)$ & 0 & 0 & 0 & 0 & 0 & 0 \\
\hline$X_{\text {Eas }}$ & 0 & $0.01(1)$ & $0.01(1)$ & 0 & 0 & 0 & 0 & 0 & 0 \\
\hline$X_{\mathrm{Vac}}{ }^{4}$ & $0.06(2)$ & $0.10(2)$ & $0.08(2)$ & $0.06(2)$ & $0.05(2)$ & 0.04 (1) & $0.03(1)$ & $0.01(1)$ & 0 \\
\hline$X_{\mathrm{Ms}}^{5}$ & $0.01(2)$ & $0.00(2)$ & 0 & 0 & 0 & 0 & 0 & 0 & 0 \\
\hline$X_{\mathrm{Mg}}{ }^{6}$ & 0 & $0.13(2)$ & $0.24(1)$ & $0.35(1)$ & $0.46(1)$ & $0.54(2)$ & $0.65(1)$ & $0.83(1)$ & 1 \\
\hline$S_{\mathrm{cal}}(\mathrm{J} /(\mathrm{mol} \cdot \mathrm{K}))$ & 411.4 (29) & $403.0(30)$ & $385.4(30)$ & $384.4(30)$ & $373.1(30)$ & $362.5(30)$ & $353.3(30)$ & $334.3(30)$ & $319.4(22)$ \\
\hline $\begin{array}{c}\delta \Delta \operatorname{corr}(175- \\
\left.640 \mathrm{~cm}^{-1}\right)\end{array}$ & & 4.502 & 2.464 & 4.986 & 3.888 & 7.63 & 5.462 & 3.756 & \\
\hline $\begin{array}{c}\delta \Delta \operatorname{corr}(800- \\
\left.1300 \mathrm{~cm}^{-1}\right)\end{array}$ & & -8.145 & -8.838 & -3.520 & -12.563 & -7.606 & -12.789 & -7.154 & \\
\hline$\Delta H_{\mathrm{ex}}^{7}(\mathrm{~kJ} / \mathrm{mol})$ & & 1.29 & 0.71 & 1.43 & 1.11 & 2.18 & 1.56 & 1.07 & \\
\hline$\Delta H_{\mathrm{ex}}^{8}(\mathrm{~kJ} / \mathrm{mol})$ & & -1.88 & -2.04 & -0.81 & -2.90 & -1.76 & -2.95 & -1.15 & \\
\hline $\mathrm{V}_{\mathrm{o}}(\mathrm{J} / \mathrm{bar})$ & $15.48(1)$ & & $15.36(1)$ & & $15.24(1)$ & & $15.14(1)$ & $15.04(1)$ & $14.96(1)$ \\
\hline
\end{tabular}

Formula units were calculated from measured wt.\% of oxides using an oxygen basis of 11. Endmember compositions are given in Table 1. Numbers in parenthesis represent one standard deviation of the mean (the number of analyses for each sample was in the range 5-15)

${ }^{1 / 2}$ From Dachs and Benisek (2015)/Dachs and Benisek (2019)

${ }^{3}$ sum of 0.08 of a siderophyllite (Sid) component, $\mathrm{K}\left(\mathrm{AlFe}^{2+}{ }_{2}\right)\left[(\mathrm{OH})_{2}\left(\mathrm{Al}_{2} \mathrm{Si}_{2}\right) \mathrm{O}_{10}\right]$, and 0.06 of a ferri-Sid component, $\mathrm{K}\left(\mathrm{Fe}^{3+} \mathrm{Fe}^{2+}{ }_{2}\right)$ $\left[(\mathrm{OH})_{2}\left(\mathrm{Fe}^{3+}{ }_{2} \mathrm{Si}_{2}\right) \mathrm{O}_{10}\right]$ (Dachs and Benisek, 2015, Table 1)

${ }^{4}$ Vacancy $(\square)$ endmember: $\mathrm{K}\left(\square \mathrm{Fe}^{3+}{ }_{2}\right)\left[(\mathrm{OH})_{2}\left(\mathrm{AlSi}_{3}\right) \mathrm{O}_{10}\right]$

${ }^{5}$ Muscovite endmember: $\mathrm{K}\left(\square \mathrm{Al}_{2}\right)\left[(\mathrm{OH})_{2}\left(\mathrm{AlSi}_{3}\right) \mathrm{O}_{10}\right]$

${ }^{6} X_{\mathrm{Mg}}=\mathrm{Mg} /\left(\mathrm{Mg}+\mathrm{Fe}^{2+}\right)$, used as compositional variable in Figs. 2 and 3

${ }^{7}$ Computed from $\Delta$ corr values (middle-wave number region $175-640 \mathrm{~cm}^{-1}$ ), based on the correlation given in Etzel and Benisek (2008), i.e., $\Delta H_{\mathrm{ex}} / \mathrm{J}=\delta \Delta \operatorname{corr} \cdot 13 \cdot \mathrm{n}$, with $n=$ number of atoms per formula unit. The term $k \cdot n o r m V^{\mathrm{exc}}$ int is zero because of ideal volumetric behaviour

${ }^{8}$ Computed from $\Delta$ corr values (high-wave number region $800-1300 \mathrm{~cm}^{-1}$ ), based on the correlation given in Etzel and Benisek (2008), i.e., $\Delta H_{\mathrm{ex}} / \mathrm{J}=\delta \Delta$ corr $\cdot 10.5 \cdot \mathrm{n}$

and $\mathrm{Phl}$ (Dachs and Benisek 2019), are shown in Fig. 1 in the temperature range $0-320 \mathrm{~K}$. A $C_{\mathrm{p}}$ anomaly, similar to that in annite and interpreted to result from a magnetic phase transition (Dachs and Benisek 2015), can be observed in Ann90Phl10 and less pronounced in Ann80Phl20 as a kink in the slope of the $C_{\mathrm{p}}$ vs. $T$ data at around $50 \mathrm{~K}$. For biotites richer in $\mathrm{Mg}$, this kink vanishes. Integrating the heat capacity data according to Eq. (1), the calorimetric entropy at $298.15 \mathrm{~K}, S_{\text {cal }}$, is plotted in Fig. 2 for the Ann-Phl binary as function of $X_{\mathrm{Mg}}$ (data from Tables 3 and 4). This figure also includes $S_{\text {cal }}$ values that have been determined from PPMS $C_{\mathrm{p}}$ measurements made on Ann-Phl samples synthesized and characterised by Redhammer et al. (2005) (Table 4). Combined with $S_{\text {cal }}=411.4 \pm 2.9 \mathrm{~J} /(\mathrm{mol} \cdot \mathrm{K}$ ) for Ann (Dachs and Benisek 2015) and $S_{\text {cal }}=319.4 \pm 2.2 \mathrm{~J} /(\mathrm{mol} \cdot \mathrm{K})$ for $\mathrm{Phl}$
(Dachs and Benisek 2019), the $S_{\text {cal }}$ vs. $X_{\mathrm{Mg}}$ data all fall on a line connecting the endmember entropies within error, which indicates ideal entropic mixing behaviour for the join. There are thus no significant excess entropies of mixing discernable and $W_{\text {AnnPhl }}^{\mathrm{S}}=0$ [the term excess quantity (vibrational entropy, enthalpy, or volume) for a given binary is the difference between the measured quantity for a specific solid solution composition minus the linear combination of the endmembers representing ideal mixing, and would be given by $X_{\mathrm{i}} \cdot X_{\mathrm{j}} \cdot W_{\mathrm{ij}}$ for the simplest case of binary symmetrical mixing between the two endmembers $\mathrm{i}-\mathrm{j}]$. The magnetic entropy contribution to $S_{\text {cal }}$ for the Ann endmember amounts to $1.5 \mathrm{~J} /(\mathrm{mol} \cdot \mathrm{K})$ (Dachs and Benisek 2015). For Ann90Phl10 and Ann80Phl20, these contributions are even smaller and 


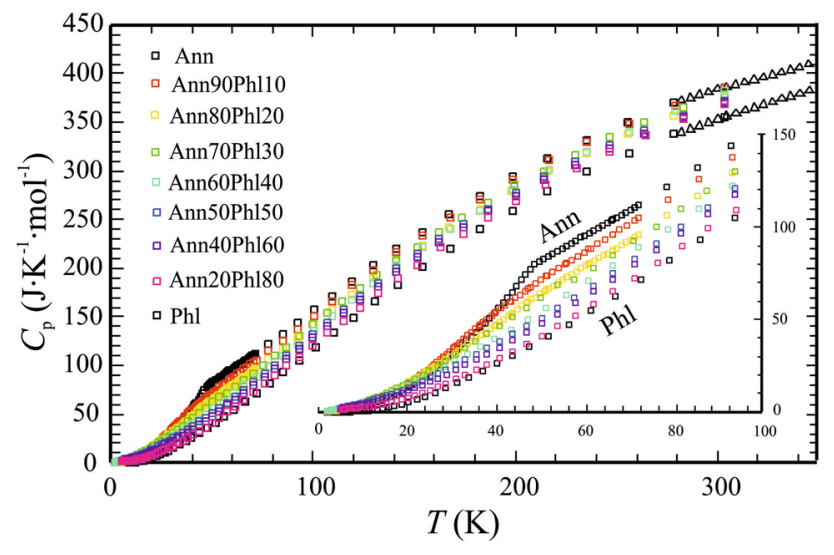

Fig. 1 PPMS-measured molar heat capacities of synthetic members of the Ann-Phl binary (Ann90Phl10, Ann80Phl20, Ann70Phl30, Ann60Phl40, Ann50Phl50, Ann40Phl60, and Ann20Ph180), in the temperature range $0-300 \mathrm{~K} . C_{\mathrm{p}}$ data for endmember Ann are from Dachs and Benisek (2015), for Phl from Dachs and Benisek (2019). The inset shows the enlarged range $0-100 \mathrm{~K}$

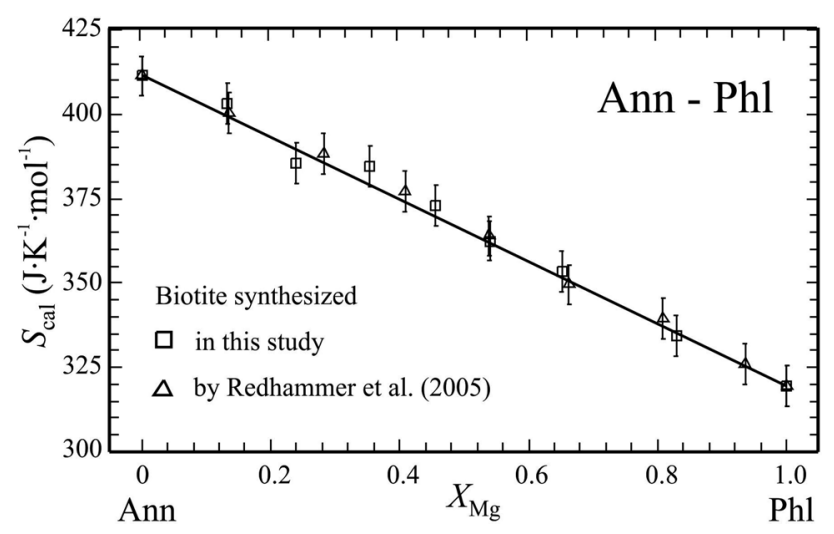

Fig. 2 Variation of calorimetric entropies, $S_{\text {cal }}$, at $298.15 \mathrm{~K}$ with bulk $X_{\mathrm{Mg}}$ along the Ann-Phl binary. Open squares: data from Table 3, open triangles: data from Table 4 . Error bars are $\pm 2 \sigma$. Line represents ideal mixing behaviour

cease to exist in more $\mathrm{Mg}$-rich biotites, but no attempt was made to quantify them.

Volumes along the Ann-Phl binary were determined by Hewitt and Wones (1975) and by Redhammer et al. (1995) on synthetic biotites, and Berman et al. (2007) contributed a volume of an intermediate synthetic $\mathrm{Ann}_{50} \mathrm{Phl}_{50}$ biotite. Plotting these literature data and that obtained in this study (Tables 3,4) as a function of composition shows a linear decrease of volumes with $X_{\mathrm{Mg}}$, with only minor scatter in the range $X_{\mathrm{Mg}}>0.4$ (Fig. 3). Redhammer et al. (1995) have also demonstrated that the molar volume of a specific solid solution member and of Ann100 shrink as a function of the $\mathrm{Fe}^{3+}$ content, as measured by Mössbauer spectroscopy. Extrapolating these data to $\mathrm{Fe}^{3+}=0$ yielded the values $V=15.403(7) \mathrm{J} /(\mathrm{bar} \cdot \mathrm{mol})$ for Ann80Phl20, 15.288(18) $\mathrm{J} /(\mathrm{bar} \cdot \mathrm{mol})$ for Ann60Phl40, 15.181(4) J/(bar.mol) for Ann40Phl60, and 15.081(3) J/(bar.mol) for Ann20Phl80 (Fig. 3, filled squares). Dachs and Benisek (2015) derived a molar volume of $15.53 \mathrm{~J} /(\mathrm{bar} \cdot \mathrm{mol})$ for 'ideal' annite in a similar manner by extrapolating volume data from annites with $\mathrm{Fe}^{3+}$ contents between the minimum values of $\sim 10$ up to $30 \%$. As these data have a considerable scatter, the extrapolated value of $V^{\circ}{ }_{\text {Ann }}$ is not well established. We prefer in this work to use a linear extrapolation of the volume data of the Ann-Phl join taking into account only volumes of $\mathrm{Fe}-\mathrm{Mg}$ biotites richer in $\mathrm{Mg}$ than $X_{\mathrm{Mg}} 0.4$. These biotites have only minor amounts of $\mathrm{Fe}^{3+}$ and the extrapolation to the $\mathrm{Fe}$ endmember yields $15.48 \mathrm{~J} /(\mathrm{bar} \cdot \mathrm{mol})$ for $V^{\mathrm{O}}$ of 'ideal' annite. Combined with a $V^{0}=14.958(3) \mathrm{J} /(\mathrm{bar} \cdot \mathrm{mol}$ ) for Phl (Dachs and Benisek 2019), the existing volume data along the AnnPhl join can be consistently described as an ideal solution, i.e., excess volumes of mixing are zero for this binary.

Tschermak-substitution related binaries: Phlogopite-eastonite, annite-siderophyllite, and annite - eastonite. Dachs and Benisek (2019) studied the Phl-Eas join calorimetrically and found that there are no vibrational excess entropies of mixing (i.e., $\mathrm{W}_{\text {PhlEas }}^{\mathrm{S}}=0$ ).

The samples calorimetrically studied herein along the Ann-Sid join were those synthesized by Benisek et al. (1996) and Redhammer et al. (2000). The characterisation of these samples via electron microprobe, XRPD, and optical microscopy can be found in these papers. $S_{\text {cal }}$ behaviour shows a linear decrease of $S_{\text {cal }}$ with increasing $\mathrm{Al}^{\mathrm{VI}}$ content (Fig. 4). Therefore, no significant excess entropies of mixing occur on the Ann-Sid binary. Siderophyllite does not exist as an endmember physically, the most $\mathrm{Al}^{\mathrm{VI}}$-rich solid solution member has $\mathrm{Al}^{\mathrm{VI}}=0.75$ (Table 5). Linear extrapolation

Table 4 PPMS-derived calorimetric (vibrational) entropies, $S_{\text {cal }}$, at 298.15 of members of the Ann-Phl binary, synthesized by Redhammer et al. (2005, Table 1) at $700{ }^{\circ} \mathrm{C}, 4 \mathrm{kbar}$, and redox conditions of the NiNiO buffer

\begin{tabular}{llllllll}
\hline & mgan0.4\#1 & mgan0.8\#1 & mgan1.2\#1 & mgan1.6\#1 & mgan2.0\#1 & mgan2.4\#1 & mgan2.8\#1 \\
\hline$X_{\mathrm{Mg}}{ }^{1}$ & 0.14 & 0.28 & 0.41 & 0.54 & 0.66 & 0.81 & 0.94 \\
$S_{\text {cal }}(\mathrm{J} /(\mathrm{mol} \cdot \mathrm{K}))$ & $400.2(30)$ & $388.3(30)$ & $377.1(30)$ & $363.9(30)$ & $349.5(30)$ & $339.4(30)$ & $326.0(30)$ \\
\hline
\end{tabular}

Numbers in parenthesis represent one standard deviation of the mean

${ }^{1}$ Computed from the compositional data given in Table 1 of Redhammer et al. (2005) 


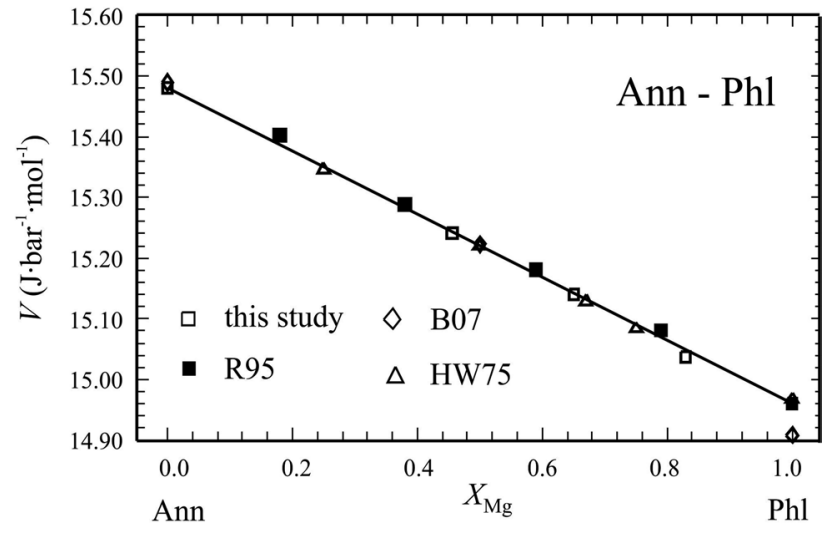

Fig. 3 Variation of molar volumes with $X_{\mathrm{Mg}}$ in $\mathrm{Fe}-\mathrm{Mg}$ biotite indicating ideal mixing behaviour. Filled squares: volumes from Redhammer et al. (1995), Fig. 2) for $\mathrm{Fe}^{3+}$-free $\mathrm{Fe}-\mathrm{Mg}$ biotites (extrapolated for individual $\mathrm{Fe}^{2+/ 3+}-\mathrm{Mg}$ biotites from the variation of their volume with $\mathrm{Fe}^{3+}$ content, see text). Open triangles: Hewitt and Wones (1975); Open squares: Berman et al. (2007). Line represents ideal mixing behaviour

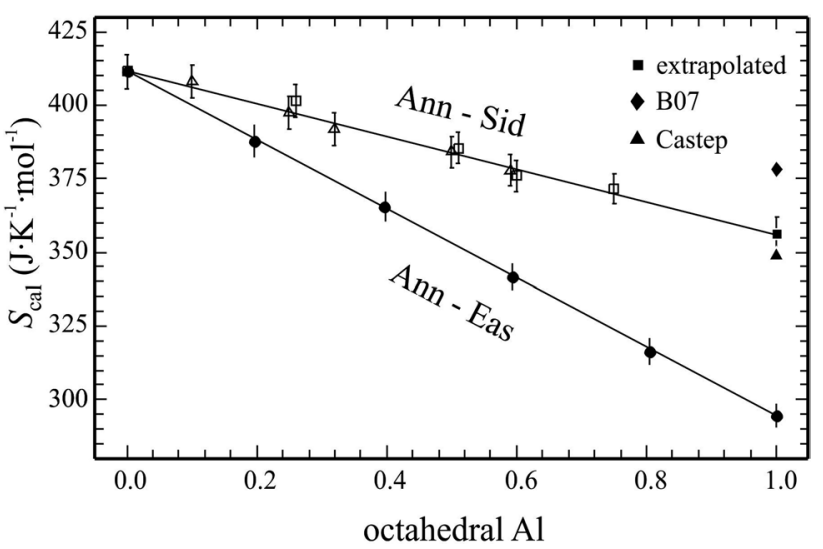

Fig. 4 Variation of calorimetric entropies, $S_{\text {cal }}$, at $298.15 \mathrm{~K}$ with $\mathrm{Al}^{\mathrm{VI}}$ along the binaries Ann-Sid (Table 5, open symbols) and AnnEas (Table 6, dots). Open squares/triangles: samples synthesized and characterised by Benisek et al. (1996)/Redhammer et al. (2000). Filled square: extrapolated $S_{\text {Sid }}^{\mathrm{o}}$ from this study; filled triangle: $S_{\text {Sid }}^{\mathrm{o}}$ for ordered Sid from CASTEP calculation; filled diamond: $S_{\text {Sid }}^{\mathrm{o}}$ according to Berman et al. (2007). Error bars are $\pm 2 \sigma$. Line represents ideal mixing behaviour

of the $S_{\mathrm{cal}^{-}} \mathrm{Al}^{\mathrm{VI}}$ data then yields a standard entropy of $S_{\text {Sid }}^{\mathrm{o}}=356.0 \pm 3.1 \mathrm{~J} /(\mathrm{mol} \cdot \mathrm{K})$. CASTEP-computed $S^{\mathrm{o}}{ }_{\text {Sid }}$, on the other hand, is somewhat lower, namely $S_{\mathrm{Sid}}^{\mathrm{o}}=348.6 \mathrm{~J} /$ $(\mathrm{mol} \cdot \mathrm{K})$ for ordered $\mathrm{Sid}(\mathrm{Al}$ on M1) and $350.6 \mathrm{~J} / \mathrm{mol} \cdot \mathrm{K}$ for a siderophyllite with $\mathrm{Al}$ on $\mathrm{M} 2$. From the DSC-measured $C_{\mathrm{p}}$ polynomials of members of the Ann-Sid join (Benisek et al. 1999), we derived the following polynomial for endmember $\operatorname{Sid}\left(C_{\mathrm{p}}\right.$ in $\left.\mathrm{J} /(\mathrm{mol} \cdot \mathrm{K})\right)$ :
$C_{P}^{S i d}=813.22-8005.32 T^{-0.5}+50698.8 T^{-2}+1.74881 \cdot 10^{8} T^{-3}$.

This was done by extrapolating heat capacities calculated from the $C_{\mathrm{p}}$ polynomials of Ann (Dachs and Benisek 2015) and of Sid21 and Sid76 (Benisek et al. 1999, Table 2) as a function of $\mathrm{Al}^{\mathrm{VI}}$ to endmember Sid composition and refitting these data to Eq. (14). $C_{\mathrm{p}}$ polynomials of intermediate Ann-Sid biotites were not used, because these are affected by excess heat capacities (Benisek et al. 1999).

The volume-composition relationship for the Ann-Sid binary was discussed by Benisek et al. (1996), and it was shown that there is no indication of excess volumes of mixing on this join (i.e., $W_{\mathrm{AnnSid}}^{\mathrm{V}}=0$ ). The molar volume of Sid was determined as $V_{S i d}^{0}=15.06 \pm 0.02 \mathrm{~J} / \mathrm{bar}$.

The Ann-Eas join is a combination of $\mathrm{Fe}-\mathrm{Mg}$ and Tschermak exchanges and may be written as:

$$
\left(3 F e^{2+}\right)^{V I}+\left(S i^{4+}\right)^{I V}=\left(2 M g^{2+}+A l^{3+}\right)^{V I}+\left(A l^{3+}\right)^{I V},
$$

or in vector notation $\mathrm{Mg}_{2}{ }^{\mathrm{VI}} \mathrm{Al}^{\mathrm{VI}} \mathrm{Al}^{\mathrm{IV}} \mathrm{Fe}_{-3}{ }^{\mathrm{VI}} \mathrm{Si}_{-1}{ }^{\mathrm{IV}}$. We have synthesized four members of this join (compositional data are given in Table 6) and measured their $S_{\text {cal }}$. Plotting these data vs. $2 \mathrm{Mg}+\mathrm{Al}^{\text {tot }}\left(=\mathrm{Al}^{\mathrm{VI}}+\mathrm{Al}^{\mathrm{IV}}\right)$, rescaled to range from 0 to 1 in Fig. 4, shows again a linear $S_{\text {cal }}$-composition relationship, i.e., all data plot on a line drawn between $S^{\circ}$ of Ann $(411.4 \pm 2.9 \mathrm{~J} /(\mathrm{mol} \cdot \mathrm{K})$, Dachs and Benisek 2015) and $S^{\mathrm{O}}$ of Eas $(294.5 \pm 3.0 \mathrm{~J} /(\mathrm{mol} \cdot \mathrm{K})$ (Dachs and Benisek 2019). Excess entropies of mixing are thus zero and $\mathrm{W}^{\mathrm{S}}$ AnnEas $=0$.

The molar volume-composition behaviour for the synthesized Ann-Eas biotites is shown in Fig. 5 (see Table 7 for structural data). Taking $V^{0}$ of Ann from above and of Eas from Dachs and Benisek (2019), a picture mirroring that of $\Delta H_{\text {ex }}$ of the Ann-Phl join emerges, i.e., $\Delta V_{\text {ex }}$ is slightly positive at $\mathrm{Mg}$ (and $\mathrm{Al}^{\mathrm{VI}}$ )-rich and slightly negative at Fe-rich (and $\mathrm{Al}^{\mathrm{VI}}$-poor) compositions. If the $\Delta V_{\mathrm{ex}}$ data were fitted to an asymmetric Margules model, which can be written for a binary solution 1-2 as (e.g., Cemič 2005):

$\Delta V_{e x}=\left(1-X_{2}\right) X_{2}^{2} W_{12}^{V}+\left(1-X_{2}\right)^{2} X_{2} W_{21}^{V}$,

$\mathrm{W}^{\mathrm{V}}{ }_{\text {AnnEas }}=0.44 \pm 0.07 \mathrm{~J} / \mathrm{bar}$ and $\mathrm{W}^{\mathrm{V}}{ }_{\text {EasAnn }}=-0.36 \pm 0.07 \mathrm{~J} /$ $\operatorname{bar}(\rho=-0.95)$ would result. Within a $2 \sigma$ error, however, the modelled volume-composition behaviour deviates only a little bit from ideality (Fig. 5). For now, we prefer to treat the Ann-Eas binary as volumetrically ideal and a more detailed study including more solid solution members of this join would be required to assess if indeed the anticipated slight deviation from ideality really exists. 
Table 5 Calorimetric (vibrational) entropies, $S_{\text {cal }}$, at 298.15 (determined from PPMS measurements) of members of the Ann-Sid binary and excess enthalpies of mixing, $\Delta c o r r$, and $\Delta H_{\mathrm{ex}}$ values (derived from line broadening in powder absorption IR spectra)

\begin{tabular}{llllllllll}
\hline Sample & Sid12 & Sid25 & Sid37 & Sid50 & Sid67 & sid25/10 & sid50/10 & sid62/10 & sid75/10 \\
\hline $\mathrm{Al}^{\mathrm{VI}}$ & $0.10(3)^{1}$ & $0.25(3)^{1}$ & $0.32(4)^{1}$ & $0.50(3)^{1}$ & $0.59(3)^{1}$ & $0.26(3)^{2}$ & $0.51(3)^{2}$ & $0.60(4)^{2}$ & $0.75(3)^{2}$ \\
$S_{\text {cal }}(\mathrm{J} /(\mathrm{mol} \cdot \mathrm{K}))$ & $408.1(30)$ & $397.4(30)$ & $391.8(30)$ & $384.0(30)$ & $377.9(30)$ & $401.5(30)$ & $385.4(30)$ & $376.0(30)$ & $371.6(30)$ \\
$\delta \Delta \operatorname{corr}\left(800-1300 \mathrm{~cm}^{-1}\right)$ & -17.3 & -9.00 & -7.80 & -10.10 & 0 & & & \\
$\Delta H_{\mathrm{ex}}{ }^{3)}(\mathrm{kJ} / \mathrm{mol})$ & -4.00 & -2.08 & -1.80 & -2.33 & 0 & & & \\
\hline
\end{tabular}

The samples were synthesized by Benisek et al. (1996) and by Redhammer et al. (2000) and have been characterised in these papers. Numbers in parenthesis are one standard deviation of the mean. $\Delta H_{\mathrm{ex}}$, derived from line broadening in IR is also given

${ }^{1}$ Benisek et al. (1996, Table 1)

${ }^{2}$ Redhammer et al. (2000, Table 2)

${ }^{3}$ Computed from $\Delta$ corr values (high-wave number region $800-1300 \mathrm{~cm}^{-1}$ ), based on the correlation given in Etzel and Benisek (2008), i.e., $\Delta H_{\mathrm{ex}} / \mathrm{J}=\delta \Delta$ corr $\cdot 10.5 \cdot \mathrm{n}$, with $n=$ number of atoms per formula unit. The term $k \cdot n o r m V^{\mathrm{exc}}{ }_{\text {int }}$ is zero because of ideal volumetric behaviour. Note that the most Al-rich composition Sid67 was used as end-member when calculating $\Delta H_{\text {mix }}$

Table 6 Formula units, mole fractions of biotite endmembers, calorimetric (vibrational) entropies, $S_{\mathrm{cal}}$, at 298.15 (determined from PPMS measurements), $\delta \Delta$ corr, and $\Delta H_{\mathrm{ex}}$ (derived from line broadening in powder absorption IR spectra) of members of the Ann-Eas join synthesized in this study

\begin{tabular}{lllll}
\hline & Ann80Eas20 & Ann60Eas40 & Ann40Eas60 & Ann20Eas80 \\
\hline $\mathrm{Si}$ & $2.83(3)$ & $2.66(1)$ & $2.48(4)$ & $2.31(1)$ \\
$\mathrm{Al}$ & $1.34(2)$ & $1.74(2)$ & $2.07(3)$ & $2.40(3)$ \\
$\mathrm{Fe}^{2+}$ & $2.12(4)$ & $1.60(2)$ & $1.08(3)$ & $0.44(2)$ \\
$\mathrm{Fe}^{3+}$ & $0.18(1)$ & $0.10(1)$ & $0.05(1)$ & $0.01(1)$ \\
$\mathrm{Mg}$ & $0.42(2)$ & $0.82(2)$ & $1.24(2)$ & $1.72(3)$ \\
$\mathrm{K}$ & $0.98(2)$ & $0.97(1)$ & $0.99(2)$ & $1.01(2)$ \\
$\mathrm{Al}^{\mathrm{IV}}-1$ & $0.17(3)$ & $0.34(2)$ & $0.52(4)$ & $0.69(3)$ \\
$\mathrm{Al}$ & $0.17(3)$ & $0.40(2)$ & $0.55(4)$ & $0.71(3)$ \\
$X_{\mathrm{Ann}}$ & $0.62(1)$ & $0.38(1)$ & $0.20(1)$ & $0.06(1)$ \\
$X_{\mathrm{Phl}}$ & $0.12(1)$ & $0.20(1)$ & $0.24(1)$ & $0.23(1)$ \\
$X_{\mathrm{Sid}}$ & $0.14(2)$ & $0.22(3)$ & $0.24(2)$ & $0.14(1)$ \\
$X_{\mathrm{Eas}}$ & $0.03(2)$ & $0.12(1)$ & $0.28(1)$ & $0.55(1)$ \\
$X_{\mathrm{Vac}}$ & $0.09(2)$ & $0.05(1)$ & $0.03(1)$ & $0.01(1)$ \\
$X_{\mathrm{Ms}}$ & $0.00(2)$ & $0.03(1)$ & $0.01(2)$ & $0.01(1) 0$ \\
$X_{\mathrm{Mg}}$ & $0.17(1)$ & $0.34(1)$ & $0.53(1)$ & $0.80(1)$ \\
$S_{\text {cal }}(\mathrm{J} /(\mathrm{mol} \cdot \mathrm{K}))$ & $387.8(30)$ & $365.3(30)$ & $341.7(30)$ & $316.3(30)$ \\
$\delta \Delta$ corr $\left(800-1300 \mathrm{~cm}^{-1}\right)$ & -9.645 & -11.482 & -13.585 & -10.087 \\
$\Delta H_{\text {ex }}(\mathrm{kJ} / \mathrm{mol})^{1}$ & -2.23 & -2.66 & -3.14 & -2.33 \\
\hline
\end{tabular}

Formula units were calculated from wt.\% of oxides, obtained by electron microprobe analyses, using an oxygen basis of 11 . Numbers in parenthesis represent one standard deviation of the mean (the number of analyses for each sample was in the range 5-15)

${ }^{1}$ Computed from $\Delta$ corr values (high-wave number region $800-1300 \mathrm{~cm}^{-1}$ ), based on the correlation given in Etzel and Benisek (2008) using $\Delta H_{\mathrm{ex}} / \mathrm{J}=\delta \Delta \operatorname{corr} \cdot 10.5 \cdot \mathrm{n}$, with $n=$ number of atoms per formula unit. The term $k \cdot n o r m V_{\text {int }}^{\text {exc }}$ is zero because of ideal volumetric behaviour

\section{Excess enthalpies of mixing $\left(\Delta H_{\mathrm{ex}}\right)$ of biotite binaries and $\Delta H_{f}^{\circ}$ values of biotite endmembers}

Published phase-equilibrium data for the reactions:

2 Phlogopite +6 Quartz $=3$ Enstatite +2 Sanidine $+2 \mathrm{H}_{2} \mathrm{O}$,

$$
\begin{aligned}
3 \text { Eastonite }+6 \text { Quartz }= & 2 \text { Phlogopite }+3 \text { Sillimanite } \\
& + \text { Sanidine }+\mathrm{H}_{2} \mathrm{O},
\end{aligned}
$$

$$
\begin{aligned}
3 \text { Siderophyllite }+6 \text { Quartz }= & 2 \text { Annite }+3 \text { Sillimanite } \\
& + \text { Sanidine }+\mathrm{H}_{2} \mathrm{O},
\end{aligned}
$$

$\frac{1}{2}$ Forsterite $+\frac{1}{3}$ Annite $=\frac{1}{2}$ Fayalite $+\frac{1}{3}$ Phlogopite

were used, in combination with some approximations discussed below, to constrain the $W^{\mathrm{H}}{ }_{\mathrm{ij}}$ parameters and to derive $\Delta H_{\mathrm{f}}^{\mathrm{o}}$ values of biotite endmembers in a single-step 


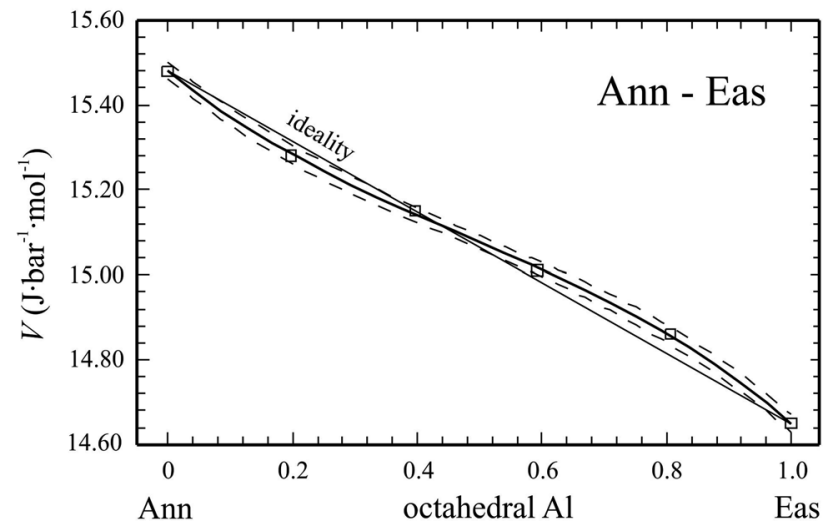

Fig. 5 Variation of molar volumes with $\mathrm{Al}^{\mathrm{VI}}$ along the Ann-Eas join (data from Table 7). Drawn curve is the modelled molar volume using $\mathrm{W}^{\mathrm{V}}$ parameters mentioned in the text. Taking the $\pm 2 \sigma$ uncertainty envelope into account (dotted lines), volumetric mixing behaviour along the join is close to being ideal. Line represents ideal mixing behaviour

least-squares procedure. In this treatment, all required thermodynamic data were taken from Holland and Powell 2011; updated data set tc-ds62.txt) except for biotite endmembers: $S_{\text {Phl }}^{\mathrm{o}}=330.9 \pm 2.2 \mathrm{~J} /(\mathrm{mol} \cdot \mathrm{K}), C_{\mathrm{p}, \mathrm{Phl}}, S_{\text {Eas }}^{\mathrm{o}}=294.5 \pm 3.0 \mathrm{~J} /$ $(\mathrm{mol} \cdot \mathrm{K})$ and $C_{\mathrm{p}, \mathrm{Eas}}$ from Dachs and Benisek (2019), and $S_{\text {Ann }}=422.9 \pm 2.9 \mathrm{~J} /(\mathrm{mol} \cdot \mathrm{K})$ and $C_{\mathrm{p}, \text { Ann }}$ from Dachs and Benisek (2015). A weighting of the experimental data was applied, based on experimental uncertainties and bracket widths (see supplementary materials for more details).

The experimental data processed were (1) the brackets obtained by Bohlen et al. (1983) Clemens (1995), Aranovich and Newton (1998) and Berman et al. (2007) on reaction (17), either in a pure $\mathrm{H}_{2} \mathrm{O}$ fluid or in fluids with reduced $\mathrm{H}_{2} \mathrm{O}$ activity $\left(\mathrm{H}_{2} \mathrm{O}-\mathrm{CO}_{2}\right.$ or $\mathrm{H}_{2} \mathrm{O}-\mathrm{KCl}$ fluids), (2) the reversals of equilibria (18) and (19) determined by Berman et al. (2007), defining the Al-saturation level of biotite in the assemblage (Fe-Mg-Al)biotite-sillimanite-sanidine-quartz under the presence of water and (3) the experimental $\mathrm{Fe}-\mathrm{Mg}$ partitioning data between biotite and olivine of Zhou (1994). The reasons for not including experimental garnet-biotite and orthopyroxene-biotite $\mathrm{Fe}-\mathrm{Mg}$ exchange data are discussed below.

The set of experimental data for reactions (17) and (18) is the same as used by Dachs and Benisek (2019) in their study of $\mathrm{Mg}-\mathrm{Al}$ biotites.

With regard to reaction (20), the thermodynamic evaluation of Zhou's partitioning data requires a value for the interaction parameter for symmetrical $\mathrm{Fe}-\mathrm{Mg}$ mixing in olivine $\left(W_{\mathrm{FaFo}}^{\mathrm{G}}\right)$. As outlined in the discussion, this parameter is relatively well known and we use a value of $W_{\text {FaFo }}^{\mathrm{G}}=5 \mathrm{~kJ} / \mathrm{mol}$ (one-site mixing). Information on the $\mathrm{Al}^{\mathrm{VI}}$ content of Zhou's biotites comes from the fact that he stated that the two endmembers $\mathrm{Phl}$ and a $\mathrm{Fe}^{3+}$-bearing 'annite' $\mathrm{K}\left(\mathrm{Fe}^{2+}{ }_{2.7} \mathrm{Fe}^{3+}{ }_{0.3}\right)$ $\left[\mathrm{AlSi}_{3} \mathrm{O}_{10.3}(\mathrm{OH})_{1.7}\right]$ were sufficient to describe the compositional variation of his biotites. The measured values of the $\mathrm{Al}$ content in biotite were, therefore, not tabulated for his exchange experiments with Ti-free biotites. For biotite bulk compositions with a Si:Al ratio of 3:1 and $0.3 \mathrm{Ti}$ apfu, however, microprobe data exist, and reactant biotites did not show a significant deviation from the $\mathrm{Si}: \mathrm{Al}=3: 1$ ratio in experiments conducted at 700 and $860{ }^{\circ} \mathrm{C}$, indicating $\mathrm{Al}^{\mathrm{VI}} \sim 0$ (Zhou (1994), his Table 2-14). The same is thus very likely for his Ti-free exchange data. No or only minor $\mathrm{Al}^{\mathrm{VI}}$ in Zhou's Ti-free biotites is also confirmed by lattice constants given for synthesized 'annite'. They yield a molar volume $V_{\mathrm{o}}=15.362 \mathrm{~J} / \mathrm{bar}$, which is consistent with $V_{\mathrm{o}}$ of an 'annite' with ca. $10 \% \mathrm{Fe}^{3+}$ (Dachs and Benisek 2015), whereas more aluminous Fe biotites would have a lower $V_{\mathrm{o}}$ (Benisek et al. 1996). Octahedral Al of biotite in Zhou's (1994) experiments was thus taken to be negligible and set to zero in our calibration, allowing a parameterization of $\mathrm{Fe}-\mathrm{Mg}$ mixing-related interaction parameters. The attainment of equilibrium in Zhou's (1994) study was demonstrated using pairs of experiments that were conducted at similar $P-T$ and $\log \mathrm{f}_{\mathrm{O} 2}$ conditions, but started on opposite sides of the Roozeboom distribution curve (pressure was $1.1 \mathrm{kbar}$, temperatures were $650,700,800$, and $860{ }^{\circ} \mathrm{C}$ and
Table 7 Lattice parameters and volumes of synthetic members of the Ann-Eas join

\begin{tabular}{lllllll}
\hline & $a(\AA)$ & $b(\AA)$ & $c(\AA)$ & $\beta\left(^{\circ}\right)$ & Volume $\left(\AA^{3}\right)$ & $\begin{array}{l}\text { Volume } \\
\mathrm{J} /(\mathrm{mol} \cdot \mathrm{bar})\end{array}$ \\
\hline Ann100 & & & & & & $15.530(10)^{1}$ \\
Ann80Eas20 & $5.3768(6)$ & $9.3580(60)$ & $10.2954(7)$ & $100.024(8)$ & $507.29(5)$ & $15.275(1)$ \\
Ann60Eas40 & $5.3560(6)$ & $9.2736(10)$ & $10.2866(7)$ & $100.042(8)$ & $503.10(5)$ & $15.148(1)$ \\
Ann40Eas60 & $5.3311(5)$ & $9.2289(10)$ & $10.2869(7)$ & $100.004(8)$ & $498.43(5)$ & $15.008(1)$ \\
Ann20Eas80 & $5.3106(13)$ & $9.1581(11)$ & $10.3019(7)$ & $99.991(8)$ & $493.44(9)$ & $14.858(2)$ \\
Eas100 & & & & & & $14.65^{2}$ \\
\hline
\end{tabular}

Numbers in parentheses are $1 \sigma$

${ }^{1}$ Dachs and Benisek (2015)

${ }^{2}$ Molar volume of ordered eastonite as derived from DFT computations (Dachs and Benisek 2019) 
$\log f_{\mathrm{O} 2}$ was controlled by the graphite-methane buffer). In one of these experiments, olivines with a high- and biotites with a low $\mathrm{Mg}$ content were used and vice versa in the second experiment. XRPD and electron microprobe techniques were used to determine the chemical composition of the finegrained $(5-10 \mu \mathrm{m})$ homogeneous run products and simultaneously checked for the occurrence of additional phases. The starting biotites used in Zhou's (1994) exchange experiments were synthesized from mixes of presynthesized kalsilite and appropriate amounts of oxides representing desired bulk compositions. The $\mathrm{Fe}$-rich product biotites in his exchange experiments with olivine had $10 \pm 2 \%$ of $\mathrm{Fe}^{\text {tot }}$ as $\mathrm{Fe}^{3+}$ and we used this value applying a linear decrease to $0 \%$ for $\mathrm{Mg}$-rich biotites to compute $X_{\mathrm{Fe}}^{\mathrm{Bt}}=\mathrm{Fe}^{2+} /\left(\mathrm{Fe}^{2+}+\mathrm{Mg}\right)$.

As can be seen from Eq. (2), our biotite model involves 11 macroscopic $W^{\mathrm{G}}$ parameters. From these, $W_{\text {PhlEas }}^{\mathrm{G}}, W^{\mathrm{G}}$ PhlEasd, and $W^{\mathrm{G}}$ EasEasd are already known from and discussed in the study of Dachs and Benisek (2019) on the thermodynamic properties of $\mathrm{Mg}-\mathrm{Al}$ biotite. As noted there, $\Delta H_{\mathrm{f} \text {,Eas }}^{\mathrm{o}}$ and $W^{\mathrm{H}}$ PhlEas could not be fixed unequivocally, and several combinations of $\Delta H_{\mathrm{f} \text {,Eas }}^{\mathrm{O}}$ and $W^{\mathrm{H}}$ PhlEas equally well reproduced the experimentally determined $\mathrm{Al}$-saturation level of $\mathrm{Mg}-\mathrm{Al}$ biotite in the assemblage biotite-sillimanite-sanidine-quartz as determined by Berman et al. (2007). For that reason, Dachs and Benisek (2019) used the experimental data for reaction (18) to establish a correlation between $\Delta H_{\mathrm{f} \text {,Eas }}^{\mathrm{o}}$ and $W_{\text {PhlEas }}^{\mathrm{H}}$ giving:

$\Delta H_{f, \text { Eas }}^{o}(\mathrm{~kJ} / \mathrm{mol})=-6348.5-0.34 W_{\text {PhlEas }}^{H}-0.002\left(W_{\text {PhlEas }}^{H}\right)^{2}$.

Based on line-broadening in powder absorption IR spectra and resulting $\delta \Delta$ corr from the mid-wave number IR region, they pinned $W^{\mathrm{H}}$ PhlEas to a value of $25.4 \mathrm{~kJ} / \mathrm{mol}$ which is consistent with the solution calorimetric data of Circone and Navrotsky (1992) (disregarding one of their measurements at $X_{\text {Eas }}=0.56$, which is possibly an outlier), indicating pronounced positive deviation from ideality for the $\mathrm{Phl}-$ Eas join. This gave $\Delta H_{\mathrm{f}, \mathrm{Eas}}^{\mathrm{o}}=-6358.5 \pm 1.4 \mathrm{~kJ} /$ mol (Eq. 21). As noted by Dachs and Benisek (2019), if, alternatively, $W^{\mathrm{H}}{ }_{\text {PhlEas }}{ }^{\Delta \text { corr }}=10 \mathrm{~kJ} / \mathrm{mol}$ from the high-wave number IR region would be used, still in accordance with the solution calorimetric data except at intermediate $X_{\text {Eas }}$, $\Delta H_{\mathrm{f}, \text { Eas }}^{\mathrm{a}}$ would change to a value of $-6352.0 \pm 1.4 \mathrm{~kJ} / \mathrm{mol}$. Because initial attempts to include $\Delta H_{\text {f,Eas }}^{\mathrm{o}}$ and $W_{\text {PhlEas }}^{\mathrm{H}}$ as free parameters in the least-squares treatment failed, giving unrealistic results, we used $W_{\text {PhIEas }}^{\mathrm{H}}=10 \mathrm{~kJ} / \mathrm{mol}$ and Eq. (21) as a constraint in the extraction procedure (see supplementary materials for more details). The reason for preferring $10 \mathrm{~kJ} / \mathrm{mol}$ over $25.4 \mathrm{~kJ} / \mathrm{mol}$ for $W^{\mathrm{H}}{ }_{\text {PhlEas }}$ in our KFMASH biotite solution model is given below.

To further reduce the number of fit parameters, the following approximations were introduced: a) in the case of symmetrical non-ideal mixing, $W_{\text {PhlObi }}^{\mathrm{G}}$ and $W^{\mathrm{G}}$ AnnObi are related to
$W_{\text {AnnPhl }}^{\mathrm{G}}$ via the relations $W_{\text {PhlObi }}^{\mathrm{G}}=1 / 3 \quad W_{\text {AnnPhl, }}^{\mathrm{G}}$ and $W_{\text {AnnObi }}^{\mathrm{G}}=2 / 3 \quad W_{\text {PhlAnn }}^{\mathrm{G}}$ (Powell and Holland 1999; Holland and Powell 2006). For our biotite solution model, which is subregular along the $\mathrm{Phl}$ - Ann join, we adopted these relations (i.e., assuming $W_{\text {PhlObi }}^{\mathrm{G}}=1 / 3\left(W_{\mathrm{AnnPhl}}^{\mathrm{G}}+W_{\text {PhlAnn }}^{\mathrm{G}}\right) / 2$ and $W_{\text {AnnObi }}^{\mathrm{G}}=$ $\left.2 / 3\left(W_{\mathrm{AnnPhl}}^{\mathrm{G}}+W_{\text {PhlAnn }}^{\mathrm{G}}\right) / 2\right)$, implying the assumption that there are no cross-site interactions for $\mathrm{Fe}-\mathrm{Mg}$ mixing.

Furthermore, due to the equivalence $W_{\text {EasObi }}^{\mathrm{G}}=W_{\text {AnnSid }}^{\mathrm{G}}$, $W_{\text {EasObi }}^{\mathrm{G}}$ can be determined from experimental constraints pertinent to the Ann-Sid join. For this and the Ann-Eas binary, negative $\Delta H_{\mathrm{ex}} \mathrm{s}$ of a few $(<3) \mathrm{kJ} / \mathrm{mol}$ at maximum are indicated from evaluating the line broadening in powder absorption IR spectra (Tables 5 and 6), implying negative values for $W^{\mathrm{H}}{ }_{\text {AnnSid }}\left(=W^{\mathrm{H}}{ }_{\text {EasObi }}\right)$ and $W^{\mathrm{H}}{ }_{\text {AnnEas. We }}$ chose to set these parameters to $W^{\mathrm{H}}{ }_{\mathrm{AnnSid}}=-5 \mathrm{~kJ} / \mathrm{mol}$ and to $W^{\mathrm{H}}{ }_{\text {AnnEas }}=-5 \mathrm{~kJ} / \mathrm{mol}$ (3-cation-basis), representing small negative deviation from ideality for the Ann-Sid and Ann-Eas joins. The available experimental data did not allow to include these interaction parameters in the least-squares procedure, as attempted calculations gave meaningless results. As uncertainty, we assume a value of $\pm 4 \mathrm{~kJ} / \mathrm{mol}(1 \sigma)$.

The two interaction parameters involving disordered eastonite Easd, $W_{\text {EasdAnn }}^{\mathrm{G}}$ and $W_{\text {EasdObi }}^{\mathrm{G}}$ were set to zero. Due to the large disordering enthalpy $\Delta H_{\text {(eq. 8) }}=34.5 \pm 3 \mathrm{~kJ}$, the proportion of the Eastd endmember is very low, so that this choice does not affect the least-squares results significantly, as checked by test calculations varying these parameters between -20 and $+20 \mathrm{~kJ} / \mathrm{mol}$.

With the above discussed approximations, the leastsquares derived values are:

$W_{\text {PhlAnn }}^{\mathrm{H}}=-8.8 \pm 8.0 \mathrm{~kJ} / \mathrm{mol}$,

$W^{\mathrm{H}}{ }_{\mathrm{AnnPhl}}=14.3 \pm 3.4 \mathrm{~kJ} / \mathrm{mol}$ (3-cation basis),

$W_{\text {PhlEas }}^{\mathrm{H}}=10.0 \pm 8.8 \mathrm{~kJ} / \mathrm{mol}$ (assigned value),

$\Delta H_{\mathrm{f}, \mathrm{Phl}}^{\mathrm{o}}=-6209.87 \pm 0.50 \mathrm{~kJ} / \mathrm{mol}$,

$\Delta H_{\mathrm{f}, \mathrm{Ann}}^{\mathrm{o}}=-5131.55 \pm 2.34 \mathrm{~kJ} / \mathrm{mol}$,

$\Delta H_{\mathrm{f} \text {,Eas }}^{\mathrm{o}}=-6352.00 \pm 3.72 \mathrm{~kJ} / \mathrm{mol}$ (using Eq. (21) as a fitting constraint),

$\Delta H_{\mathrm{f}, \mathrm{Sid}}^{\mathrm{o}}=-5635.83 \pm 1.60 \mathrm{~kJ} / \mathrm{mol}$.

A matrix containing the correlation coefficients from the least-squares fit is given in Table S3, Table 8 gives a summary of all mixing parameters of the $\mathrm{Fe}-\mathrm{Mg}-\mathrm{Al}$ biotite solution model from this study, and in Table 9, the endmember thermodynamic properties are compiled.

Figure 6 is a plot of the predicted $\Delta H_{\mathrm{ex}}$ vs. $X_{\mathrm{Mg}}$ for the Ann-Phl binary. It is negatively deviating from ideality with ca. $-0.5 \mathrm{~kJ} / \mathrm{mol}$ at maximum at Fe-rich biotite compositions and a positive deviation of around $1.5 \mathrm{~kJ} / \mathrm{mol}$ occurs at $X_{\mathrm{Mg}}=0.75$. The meaningfulness of such a $\Delta H_{\mathrm{ex}}$ behaviour is given in the discussion. $\delta \Delta$ corr values derived from linebroadening in powder absorption IR spectra from the highwave number region of $800-1300 \mathrm{~cm}^{-1}$ (Table 3, Fig. S1) indicate a positive $\Delta H_{\mathrm{ex}}$ of at maximum $\sim 2 \mathrm{~kJ} / \mathrm{mol}$. Using 
Table $8 \mathrm{Fe}-\mathrm{Mg}-\mathrm{Al}$ biotite mixing properties (apply for site multiplicities of endmember formulae given in Table 1)

\begin{tabular}{lllll}
\hline Mixing & $W^{\mathrm{G}}{ }_{\mathrm{ij}}{ }^{1}$ & $W^{\mathrm{H}}{ }_{\mathrm{ij}}$ & \multicolumn{2}{c}{ References $^{2}$} \\
\cline { 3 - 4 } & $\mathrm{ij}$ & $\mathrm{kJ} / \mathrm{mol}$ & Method & \\
\hline Fe-Mg & AnnPhl & $14.3 \pm 3.4$ & Exp.: Z94 & This study \\
& PhlAnn & $-8.8 \pm 8.0$ & Exp.: Z94 & This study \\
Mg-Al & PhlEas & $10.0 \pm 8.8^{3}$ & IR mid & This study, DB19 \\
& PhlEasd & 0 & DFT & DB19 \\
& EasEasd & 0 & DFT & DB19 \\
Fe-Al & AnnSid & $-5 \pm 4^{5}$ & Exp.: B07 & This study, B96 \\
(Fe/Mg)-Al & AnnEas & $-5 \pm 4^{5}$ & Exp.: B07 & This study \\
& AnnEasd & 0 & Uncritical $^{6}$ & This study \\
& ObiEasd & 0 & Uncritical $^{6}$ & \\
\hline
\end{tabular}

Standard state thermodynamic data of biotite endmembers are given in Table 9

${ }^{1} W^{\mathrm{G}}{ }_{\mathrm{ij}}=W^{\mathrm{H}}{ }_{\mathrm{ij}}-\mathrm{T} \cdot W^{\mathrm{S}}{ }_{\mathrm{ij}}+\mathrm{P} \cdot \mathrm{W}^{\mathrm{V}}{ }_{\mathrm{i}, \mathrm{j}}$. Note that $W^{\mathrm{S}} \mathrm{ij}$ 's and $W^{\mathrm{V}}$, 's are zero for all joins. The $W_{\mathrm{ij}}$ 's are compatible with an enthalpy change of $-2 \mathrm{~kJ} /$ mol for the $\mathrm{Fe}-\mathrm{Mg}$ ordering reaction $2 / 3 \mathrm{Phl}+1 / 3 \mathrm{Ann}=\mathrm{Obi}$, and an enthalpy value of $34.5 \mathrm{~kJ} / \mathrm{mol}$ for the disordering of Eas

${ }^{2}$ DB19: Dachs and Benisek (2019); Z94: Zhou (1994); B07: Berman et al. (2007); B96: Benisek et al. (1996)

${ }^{3}$ Based on the correlation between $\Delta H_{\text {f,Eas }}^{\mathrm{o}}$ and $W^{\mathrm{H}}$ Phl,Eas (Dachs and Benisek 2019, Eq. 18), this value is compatible with $\Delta H_{\text {f,Eas }}^{\mathrm{o}}=-6352.0 \mathrm{~kJ} / \mathrm{mol}$

${ }^{4}$ Note the equality $W^{\mathrm{G}}{ }_{\text {AnnSid }}=W^{\mathrm{G}}$ EasObi (Powell and Holland 1999; Holland and Powell 2006). $W^{\mathrm{G}}$ PhlObi and $W^{\mathrm{G}}{ }_{\text {Annobi }}$ were assumed to follow the relations $W^{\mathrm{G}}$ PhlObi $=1 / 3\left(W_{\text {AnnPhl }}^{\mathrm{G}}+W_{\text {PhlAnn }}^{\mathrm{G}}\right) / 2$ and $W$ ${ }_{\text {AnnObi }}=2 / 3\left(W_{\text {AnnPhl }}^{\mathrm{G}}+W_{\text {PhlAnn }}^{\mathrm{G}}\right) / 2$

${ }^{5}$ Assumed uncertainty

${ }^{6}$ The value of this parameter was set to zero. It has an only very minor effect in the thermodynamic analysis of the experimental data

the low-wave number region of the spectra $\left(175-640 \mathrm{~cm}^{-1}\right)$, on the other hand, results in a somewhat negative $\Delta H_{\mathrm{ex}}$ of $-3 \mathrm{~kJ} / \mathrm{mol}$ at maximum. $\Delta H_{\mathrm{ex}}$ resulting from $\delta \Delta$ corr values is thus expected to be rather small in magnitude, in agreement with that derived from the exchange experiments of Zhou (1994), but it is not clear from the line broadening if the sign of $\Delta H_{\mathrm{ex}}$ is positive or negative.

In the initial stage of data fitting, a symmetric mixing model was alternatively tested, which gave $\Delta H_{\text {f,Ann }}^{\circ}=-5136.7 \pm 2.1 \mathrm{~kJ} / \mathrm{mol}$, and $\mathrm{W}_{\mathrm{AnnPhl}}=9.3 \pm 1.8 \mathrm{~kJ} /$ mol. This resulted in a positive $\Delta H_{\text {ex }}$ of $2.3 \mathrm{~kJ} / \mathrm{mol}$ at maximum. Such a model, however, was discarded, because it has (1) a larger reduced $\chi^{2}$ and is (2) not capable of representing the structural/physical peculiarities of the Ann-Phl join (see below, where DFT calculations are discussed comparing annite's octahedral site with that in fayalite and ferrosilite). Furthermore, as outlined in part-II, using this $\Delta H_{\mathrm{f}, \mathrm{Ann}}^{\mathrm{a}}$ and $W_{\text {AnnPhl }}$ from the symmetric model would (3) imply a rather unrealistically large nonideality for $\mathrm{Fe}-\mathrm{Mg}$ mixing in garnet ( $W_{\text {AlmPy }}^{\mathrm{G}}$ around $12 \mathrm{~kJ} / \mathrm{mol}, 3$-site cation basis), to achieve consistency with the experimental data of Ferry and Spear (1978) on the Fe-Mg distribution between biotite and garnet.

\section{Discussion}

\section{Standard enthalpy of formation values of biotite endmembers}

The extracted $\Delta H_{\mathrm{f}, \mathrm{Ann}}^{\mathrm{o}}=-5131.55 \pm 2.34 \mathrm{~kJ} / \mathrm{mol}$ is 13-15 kJ less negative than values of $\Delta H_{\mathrm{f}, \mathrm{Ann}}^{\mathrm{o}}$ from thermodynamic databases and other determinations $\left(\Delta H_{\mathrm{f}, \mathrm{Ann}}^{\mathrm{o}}=-5144.23 \mathrm{~kJ} / \mathrm{mol}\right.$ according to Holland and Powell (2011); $\Delta H_{\mathrm{f}, \mathrm{Ann}}^{\mathrm{o}}=-5146.1 \mathrm{~kJ} / \mathrm{mol}$ according to Berman et al. (2007)). One reason for that is the use of the revised standard entropy of Phl from Dachs and Benisek (2019) in our study. $S^{\circ}$ of Phl was determined in that work

Table 9 Standard state (1 bar, $298.15 \mathrm{~K}$ ) thermodynamic properties of biotite endmembers annite (Ann), phlogopite (Phl), ordered eastonite (Eas), and siderophyllite (Sid) as derived in this study. $C_{\mathrm{p}}=\mathrm{k}_{0}+\mathrm{k}_{1} \cdot T^{-0.5}+\mathrm{k}_{2} \cdot T^{-2}+\mathrm{k}_{3} \cdot T^{-3}(\mathrm{~J} /(\mathrm{mol} \cdot \mathrm{K}))$

\begin{tabular}{lllllrr}
\hline & $\begin{array}{l}\Delta H_{\mathrm{f}}^{\mathrm{o}} \\
\mathrm{kJ} / \mathrm{mol}\end{array}$ & $S^{\mathrm{o}}$ & $V^{\mathrm{o}}$ & $\mathrm{k}_{0}$ & $\mathrm{k}_{1}$ & $\mathrm{k}_{2} \cdot 10^{-7}$ \\
\hline Ann & $-5131.55 \pm 2.34$ & $\mathrm{~J} /(\mathrm{mol} \cdot \mathrm{K})$ & $\mathrm{J} /(\mathrm{mol} \cdot \mathrm{bar})$ & & & $\mathrm{k}_{3} \cdot 10^{-9}$ \\
Phl & $-6209.87 \pm 0.50$ & $330.9 \pm 2.2^{2}$ & 14.96 & $728.6^{4}$ & -5581 & -0.2896 \\
Eas & $-6352.00 \pm 3.72^{3}$ & $294.5 \pm 3.0^{2}$ & 14.65 & $667.4^{5}$ & -3914 & -1.5240 \\
Sid & $-5635.83 \pm 1.60$ & $356.0 \pm 3.1$ & 15.06 & $656.9^{6}$ & -3622 & -1.7098 \\
\hline
\end{tabular}

${ }^{1}$ Dachs and Benisek (2015)

${ }^{2}$ Dachs and Benisek (2019)

${ }^{3}$ compatible with $W_{\text {PhlEas }}^{\mathrm{H}}=10 \mathrm{~kJ} / \mathrm{mol}$

${ }^{4} C_{\mathrm{p}}$ coefficients fitted from DSC data in the range 280-630 K (Dachs and Benisek 2015)

${ }^{5} C_{\mathrm{p}}$ coefficients fitted from DSC data in the range 280-750 K, combined with CASTEP-derived $C_{\mathrm{p}}$ up to $1000 \mathrm{~K}$ (Dachs and Benisek 2019)

${ }^{6} C_{\mathrm{p}}$ coefficients fitted from DSC data in the range 280-560 K, combined with CASTEP-derived $C_{\mathrm{p}}$ up to $1000 \mathrm{~K}$ (Dachs and Benisek 2019)

${ }^{7} C_{\mathrm{p}}$ coefficients extrapolated from those given by Benisek et al. (1999) for members of the Ann-Sid binary 
through relaxation calorimetry on a synthetic pure $\mathrm{Phl}$ $\left(S_{\mathrm{cal}, \mathrm{Phl}}=319.4 \pm 2.2 \mathrm{~J} / \mathrm{mol} \cdot \mathrm{K}\right)$ and found to be significantly larger compared to previous calorimetric determinations on a natural near endmember Phl, which formed the base for later databases $\left(S_{\text {cal }, \text { Phl }}=315.9 \pm 1.0 \mathrm{~J} / \mathrm{mol} \cdot \mathrm{K}\right.$ according to Robie and Heminway (1984)). Another reason is that the set of experimental data used in the extraction procedures is not identical.

Our determination of $\Delta H_{\mathrm{f}, \mathrm{Ann}}^{\mathrm{g}}$ is in good agreement to that extracted by Dachs and Benisek (2015) from (redox-) equilibria in the FASH system $\left(\Delta H_{\mathrm{f}, \mathrm{Ann}}^{\mathrm{a}}=-5132.5 \pm 2.0 \mathrm{~kJ} /\right.$ mol). If $\Delta H_{\mathrm{f}, \mathrm{Ann}}^{\mathrm{o}}=-5131.55 \mathrm{~kJ} / \mathrm{mol}$ is used to compute the hydrogen fugacity $\mathrm{f}_{\mathrm{H} 2}$ of the equilibrium:

Annite $=$ Sanidine + Magnetite $+\mathrm{H}_{2}$

(all other data from Holland and Powell (2011) at $2 \mathrm{kbar}$ and $700{ }^{\circ} \mathrm{C}$, one gets $\mathrm{f}_{\mathrm{H} 2}=52 \mathrm{bar}$, well within $46.3-61.4$ bar as determined experimentally for annite $\left(a_{\mathrm{Ann}}=0.64\right)$ in equilibrium with sanidine + magnetite $+\mathrm{H}_{2}$ (Dachs 1994; Benisek et al. 1996). The experimental reversals of Dachs and Benisek (1995) on the reaction:

2 Annite +3 Quartz $=2$ Sanidine +3 Fayalite $+2 \mathrm{H}_{2} \mathrm{O}$

determined experimentally in cold-seal pressure vessels between pressures of 2 and $5 \mathrm{kbar}$, could also be reproduced, if a small correction of $+1 \mathrm{~kJ}$, well within the uncertainty limits of the least-squares result, is applied to $\Delta H_{\text {f,Ann }}^{\mathrm{r}}$. The annite standard state properties determined herein (Table 9) thus enable an internal consistency between the $\mathrm{Fe}-\mathrm{Mg}$ exchange experiments of Zhou (1994) and the experimental data on reactions (22) and (23) in the FASH subsystem (Eugster and Wones 1962; Dachs 1994; Dachs and Benisek 1995).

The calorimetrically determined $S^{\mathrm{o}}{ }_{\mathrm{Sid}}=356.0 \pm 3.1 \mathrm{~J} /$ $(\mathrm{mol} \cdot \mathrm{K})$ of our study is some $20 \mathrm{~J} /(\mathrm{mol} \cdot \mathrm{K})$ smaller than $S_{\text {Sid }}^{\mathrm{o}}=378.09 \mathrm{~J} /(\mathrm{mol} \cdot \mathrm{K})$ given by Berman et al. (2007) for this endmember. Enthalpy of formation values from our study compared to theirs differs by $\sim 14 \mathrm{~kJ} /$ mol $\left(\Delta H_{\mathrm{f}, \mathrm{Sid}}^{\mathrm{o}}=-5635.83 \pm 1.6 \mathrm{~kJ} / \mathrm{mol}\right.$ compared to $\left.\Delta H_{\mathrm{f}, \mathrm{Sid}}^{\mathrm{o}}=-5621.14 \mathrm{~kJ} / \mathrm{mol}\right)$.

The enthalpy of formation values of Ann and $\mathrm{Phl}$ and the $\mathrm{Fe}-\mathrm{Mg}$ mixing properties of biotite (Table 8) derived in our study are not independent, but are correlated to the $\mathrm{Fe}-\mathrm{Mg}$ mixing properties adopted for olivine that appears as $\mathrm{Fe}-\mathrm{Mg}$ exchange partner of biotite in Eq. (20). The forsterite (Fo)-fayalite (Fa) system is well studied and most thermodynamic analyses of various phase-equilibrium data point to a moderate positive deviation from ideality that can be modelled with a symmetric macroscopic one-site $W_{\mathrm{FoFa}}^{\mathrm{G}}$ in the order of 3-6 kJ/mol mol (Davidson and Mukhopadhyay 1984; Wiser and Wood 1991; Berman and Aranovich 1996). The calorimetric study of Kojitani and Akaogi (1994) is with a slight temperature-dependent one-site $W_{\mathrm{FoFa}}^{\mathrm{G}}$ around
$5 \mathrm{~kJ} / \mathrm{mol}$ in accordance with these assertions. The earlier solution calorimetric measurements of Wood and Kleppa (1981) yielded a similar small positive deviation from ideality that is, however, asymmetric towards the Fe- endmember, characterised by the one-site interaction parameters $W_{\mathrm{FaFo}}^{\mathrm{G}}=4.2 \mathrm{~kJ} / \mathrm{mol}$ and $W_{\mathrm{FoFa}}^{\mathrm{G}}=2.1 \mathrm{~kJ} / \mathrm{mol}$.

We have measured the line broadening in powder absorption IR spectra of Fo-Fa olivines studied calorimetrically by Dachs et al. (2007). Our results agree with the above calorimetric and phase-equilibrium determinations and give a similar mean value of $W_{\mathrm{FoFa}}^{\mathrm{G}}=5 \mathrm{~kJ} / \mathrm{mol}$ per site (more details are given in supplementary Figs. S2 and S3). Because the majority of studies provide evidence for such a small positive deviation from ideality for $\mathrm{Fe}-\mathrm{Mg}$ mixing in olivine, we prefer to use $W_{\mathrm{FoFa}}^{\mathrm{G}}=5 \mathrm{~kJ} / \mathrm{mol}$ (one-site mixing) in analysing the exchange experiments of Zhou (1994).

It should, however, be noted that the studies of Sack (1980) and Sack and Ghiorso (1989) point to a larger Fe-Mg nonideality in olivine than represented by $W_{\mathrm{FoFa}}^{\mathrm{G}}=5 \mathrm{~kJ} / \mathrm{mol}$ (one-site mixing), namely $W_{\mathrm{FoFa}}^{\mathrm{G}}$ around $10 \mathrm{~kJ} / \mathrm{mol}$. If this value would be adopted and symmetrical $\mathrm{Fe}-\mathrm{Mg}$ mixing in biotite would be assumed in the thermodynamic analysis, the least-squares derived enthalpy of Ann and the interaction parameter for symmetrical $\mathrm{Fe}-\mathrm{Mg}$ mixing would change to (other enthalpies change only minor):

$$
\begin{aligned}
& \Delta H_{\mathrm{f}, \mathrm{Ann}}^{\mathrm{o}}=-5142.7 \pm 2.10 \mathrm{~kJ} / \mathrm{mol} \text { and } \\
& W_{\mathrm{PhlAnn}, \mathrm{sym}}^{\mathrm{H}}=26.0 \pm 1.7 \mathrm{~kJ} / \mathrm{mol} .
\end{aligned}
$$

The consequence of accepting this larger $W_{\mathrm{FoFa}}^{\mathrm{G}}$ in the thermodynamic treatment would be that $H_{\text {f,Ann }}^{\mathrm{o}}$ decreases by $\sim 12 \mathrm{~kJ} / \mathrm{mol}$ and that symmetrical $\mathrm{Fe}-\mathrm{Mg}$ mixing in biotite becomes strongly positive over the whole compositional range implying a rather large $\Delta H_{\mathrm{ex}}$ in the order of $6.5 \mathrm{~kJ} /$ mol at maximum.

Treating, on the other hand, the Phl-Ann join as asymmetric, as preferred in this study, using a $W_{\mathrm{FoFa}}^{\mathrm{G}}=10 \mathrm{~kJ} /$ mol (one-site cation basis) in the least-squares procedure would lead to:

$$
\begin{aligned}
& \Delta H_{\text {f,Ann }}^{\mathrm{o}}=-5136.2 \pm 1.7 \mathrm{~kJ} / \mathrm{mol} \text { and } \\
& W_{\text {PhlAnn }}^{\mathrm{H}}=0.9 \pm 6.1 \mathrm{~kJ} / \mathrm{mol}, W^{\mathrm{H}}{ }_{\text {AnnPhl }}=36.4 \pm 2.4 \mathrm{~kJ} / \mathrm{mol} .
\end{aligned}
$$

Mixing along the Phl-Ann binary would then be predicted to be strongly asymmetric towards the Ann endmember with a large maximal $\Delta H_{\mathrm{ex}}$ of around $5 \mathrm{~kJ} / \mathrm{mol}$ (see companion paper for implications on phase relations).

\section{Fe-Mg mixing in biotite: Does it resemble that in olivine?}

From the existing $\mathrm{Fe}-\mathrm{Mg}$ exchange experiments involving biotite, we have only used that of Zhou (1994), because the $\mathrm{Fe}-\mathrm{Mg}$ mixing properties of its exchange partner olivine seem to be the relative best known. Excess entropies along 
the Ann-Phl join are ideal (Fig. 2), so that there is no temperature dependence of the mixing properties $\left(\right.$ as $W_{\mathrm{ij}}^{\mathrm{V}} \mathrm{s}$ are zero for all biotite joins, $W_{\mathrm{ij}}^{\mathrm{G}} \equiv W_{\mathrm{ij}}^{\mathrm{H}}$ ). We refrained from using experimental garnet-biotite $\mathrm{Fe}-\mathrm{Mg}$ exchange data (Ferry and Spear 1978; Perchuk and Lavrent'eva 1983; Gessmann et al. 1997), because, first, conflicting data exist, and, second, the $\mathrm{Fe}-\mathrm{Mg}$ mixing properties of garnet are not as well established as those for olivine and a range of values for the $\mathrm{Fe}-\mathrm{Mg}$ parameter(s) has been proposed (e.g., Ganguly et al. (1996): $W^{\mathrm{H}}{ }_{\mathrm{AlmPy}}=2.1 \mathrm{~kJ} / \mathrm{mol}$, $W_{\text {PyAlm }}^{\mathrm{H}}=6.4 \mathrm{~kJ} / \mathrm{mol}$; Berman (1990): $W^{\mathrm{H}}$ AlmPy $=0.2 \mathrm{~kJ} /$ $\mathrm{mol}, W_{\text {PyAlm }}^{\mathrm{H}}=3.7 \mathrm{~kJ} / \mathrm{mol}$; Berman and Aranovich (1996): $W^{\mathrm{H}}{ }_{\text {AlmPy }}=5.1 \mathrm{~kJ} / \mathrm{mol}, W^{\mathrm{H}}{ }_{\text {PyAlm }}=6.2 \mathrm{~kJ} / \mathrm{mol}$; White et al. (2014a): symmetric $W_{\text {AlmPy }}^{\mathrm{G}}=2.5 \mathrm{~kJ} / \mathrm{mol}$; all values on a 3 -cation basis, Alm = almandine, $\mathrm{Py}=$ pyrope). Furthermore, existing solution calorimetric work on Alm-Py garnets (Geiger et al. 1987) shows relatively large errors on $\Delta H_{\text {mix }}$ prohibiting to extract well-defined $W_{\mathrm{H}}$ s for that join.

The experimental orthopyroxene-biotite $\mathrm{Fe}-\mathrm{Mg}$ exchange data of Fonarev and Konilov (1986) have not been used, because orthopyroxene was notably inhomogeneous in the experimental runs (see part-II for more details). In the companion paper, the existing garnet-biotite and orthopyroxene-biotite $\mathrm{Fe}-\mathrm{Mg}$ exchange data are, however, discussed and used for validation purposes of our new activity model of biotite.

Our thermodynamic analysis yields a lower reduced $\chi^{2}$ for an asymmetric biotite solution model with $W_{\mathrm{H}, \mathrm{AnnPhl}}=14.3 \pm 3.4 \mathrm{~kJ} / \mathrm{mol}$ and $W_{\mathrm{H}, \mathrm{PhlAnn}}=-8.8 \pm 8.0 \mathrm{~kJ} /$ mol. Fe-Mg mixing behaviour of biotite according to this treatment is thus characterised by a slightly negative $\mathrm{G}_{\mathrm{ex}}$ at Fe-rich compositions switching to positive $G_{\text {ex }}$ in the $\mathrm{Mg}$ rich part of the Phl-Ann binary (Fig. 6). Such a $G_{\text {ex }}$ vs. composition behaviour seems reasonable, because Ann does not exist as an endmember due to the misfit between the larger octahedral and the smaller tetrahedral sheet (e.g., Hazen and Wones (1973); Redhammer et al. (1993)). A negative $G_{\text {ex }}$ takes this fact into account by destabilising endmember Ann relative to solid solution biotites where some of the Fe is replaced by either $\mathrm{Al}$ or $\mathrm{Mg}$. Absolute values of $G_{\text {ex }}$ are, however, rather small $(<2 \mathrm{~kJ} / \mathrm{mol})$ and not far from ideality. Benisek et al. (1999) have shown that natural biotites, when their amount of $\mathrm{Al}^{\mathrm{VI}}$, as balanced by the Tschermak-substitution $\left(\mathrm{Al}^{\mathrm{IV}}-1\right)$, is plotted vs. $\mathrm{Mg} /(\mathrm{Mg}+\mathrm{Fe})$, accumulate in a band limited by a tetrahedral rotation angle of $\alpha=8 \pm 1^{\circ}$ (Hazen and Burnham 1973) (see also Fig. 12 in part-II). Biotites with that structural feature seem to be more stable than others, possibly because the misfit between the tetrahedral sheet and an octahedral layer having this $\alpha$ is minimal and smaller compared to cases where $\alpha$ is either smaller or larger. Along the Ann-Sid join, this situation is realised for biotites around the Ann50Sid50 composition, whereas on the PhlEas binary only a small degree of Tschermak substitution is required, i.e., Phl90Eas10 (Benisek et al. 1999, Fig. 10). The thermodynamic mixing behaviour of KFMASH biotites, as proposed in this study, is consistent with that picture: $\mathrm{Fe}$-rich and $\mathrm{Al}^{\mathrm{VI}}$-poor biotites around the Ann endmember have smaller $\alpha$ 's (the octahedral sheet is larger, i.e., more stretched compared to the energetically favoured ca. $8^{\circ}$ structural situation) and can reach that value by incorporation of either $\mathrm{Al}\left(\right.$ or $\mathrm{Fe}^{3+}$ ) or $\mathrm{Mg}$ or both. This behaviour can be modelled with negative deviation from ideality starting at the Ann endmember towards Sid and Phl. Mg-rich and $\mathrm{Al}^{\mathrm{VI}}$-poor biotites, on the other hand, are already in their 'optimal $\alpha$-state' and a further increase of the Tschermak substitution causes $\alpha$ 's larger than the preferred $8^{\circ}$ value. This constitutes an energetically more unfavourable situation and is thermodynamically mimicked by positive deviation from ideality along the Phl-Eas binary, as well established from solution calorimetry (Circone and Navrotsky 1992) stabilising $\mathrm{Al}^{\mathrm{VI}}$-poor $\mathrm{Mg}$-rich biotites. As a consequence of these opposite mixing behaviours (negative deviation from ideality along the Ann-Sid join, positive deviation for the Phl-Eas binary), Fe-Mg mixing in biotite is then predicted to deviate negatively from ideality for Fe-rich compositions switching to positive deviation at intermediate $X_{\mathrm{Mg}}$ (Fig. 6).

In the more recent literature and in relation to the development of internally consistent thermodynamic databases and corresponding software, which allow the computation of various types of phase diagrams, $\mathrm{Fe}-\mathrm{Mg}$ mixing in biotite itself was linked to that in $\mathrm{Fe}-\mathrm{Mg}$ olivine. This was done by assuming that the value of the microscopic interaction parameter, which describes the energy between a $\mathrm{Fe}^{2+}$ and $\mathrm{Mg}$ atom mixing on one octahedral site $\left(w_{\mathrm{FeMg}, \mathrm{oct}}\right)$, is the same as that for olivine, namely around $4 \mathrm{~kJ} \cdot \mathrm{mol}^{-1}$. For three octahedral sites as in biotite, $W_{\text {PhlAnn }}$ then becomes $12 \mathrm{~kJ} /$ mol (Holland and Powell 2006). This idea of defining microscopic interaction $w$ 's from (well) known mineral systems and transferring them to experimentally less or unknown systems is the basis of the heuristic approach of Powell et al. (2014), called 'micro- $\Phi$ '. In this process, the microscopic $w$ 's get reassembled into corresponding macroscopic $W$ 's by multiplying with the minerals site multiplicities and these can then be used in activity model calculations. The asymmetric type of $\mathrm{Fe}-\mathrm{Mg}$ mixing behaviour which we extracted for biotite from experimental data is not in accordance with that resulting from the micro- $\Phi$ ' approach, where the $w$ 's are transferred between different mineral systems. On the microscopic level, the underlying hypothesis ( $\left.w_{\mathrm{FeMg} \text {,one-oct-site }}\right)^{\text {miner }}$ ${ }^{\mathrm{al}}=\left(w_{\text {FeMg,one-oct-site }}\right)^{\text {olivine }}=4 \mathrm{~kJ} / \mathrm{mol}$ can be expected to be a good approximation, if the octahedral sites in 'mineral' (e.g., biotite, pyroxene, etc.) have comparable geometries and thus energies to that in olivine. In Table 10, we have listed the range of octahedral $\mathrm{Fe}-\mathrm{O}$ distances and their mean values for Ann, ferrosilite (Fs) and $\mathrm{Fa}$ resulting from additional CASTEP calculations that we have undertaken. Whereas the 
Table $10 \mathrm{Fe}-\mathrm{O}$ distances in octahedral sites of annite (Ann), compared to fayalite $(\mathrm{Fa})$ and Ferrosilite $(\mathrm{Fs})$ from DFT calculations

\begin{tabular}{lll}
\hline & $\begin{array}{l}\text { Fe-O distance } \\
\text { Range }\end{array}$ & $\begin{array}{l}\text { Fe-O distance } \\
\text { Mean }\end{array}$ \\
& $\AA$ & $\AA$ \\
\hline Ann & $2.04-2.14$ & 2.09 \\
$\mathrm{Fa}$ & $2.04-2.26$ & 2.14 \\
$\mathrm{Fs}$ & $1.98-2.50$ & 2.15 \\
\hline
\end{tabular}

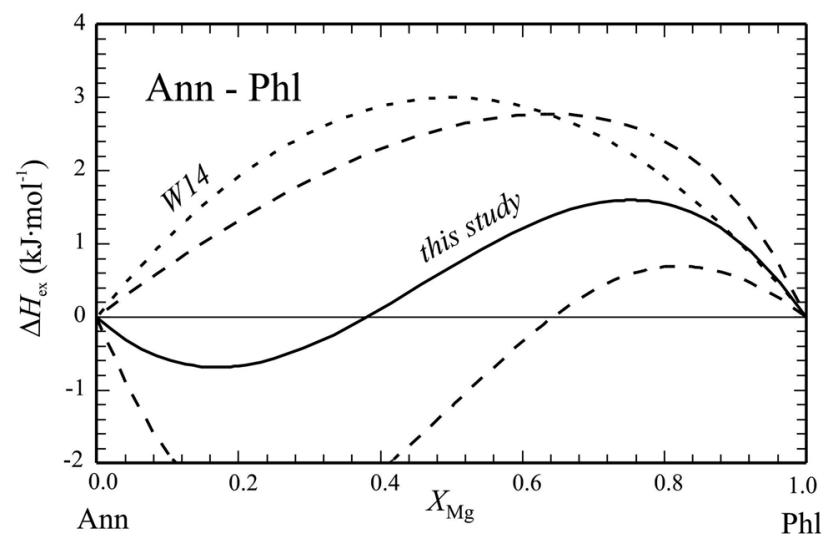

Fig. $6 \Delta H_{\mathrm{ex}}$ along the Ann-Phl binary, as derived in this study from the experimental $\mathrm{Fe}-\mathrm{Mg}$ exchange experiments between biotite and olivine of Zhou (1994), calculated with the $\mathrm{W}^{\mathrm{H}}$ parameters given in Table 8 (thick line; long-dashed curves are the $\pm 2 \sigma$ uncertainty envelope). The short-dashed curve represents $\Delta H_{\text {ex }}$ computed based on the assumption that $\mathrm{Fe}-\mathrm{Mg}$ mixing in biotite resembles that in olivine (see text)

mean $\mathrm{Fe}-\mathrm{O}$ distance in ferrosilite is with a value of $2.15 \AA$ quite similar to that in Fayalite (2.14 $\AA$ ), the corresponding distance in Ann is significantly smaller (2.09 $\AA$ ). The range of $\mathrm{Fe}-\mathrm{O}$ distances within an octahedral site in Ann is also smaller compared to that in Fs and Fa (Table 10). The M sites in Ann are thus more 'compressed' relative to that in Fa und Fs. Octahedral flattening has been described as a major distortion mechanism besides tetrahedral rotation to accommodate the misfit between octahedral and tetrahedral sheets in biotite (Mercier 2006). In conclusion, our CASTEP calculations show that the transferability of microscopic $w$ 's from olivine to $\mathrm{Fe}-\mathrm{Mg}$ pyroxenes seems reasonable but not in the case of biotite, where the octahedra are too different compared to the ones in olivine. However, one has to note that the mean site geometry for ferrosilite in this comparison is the mean of two octahedral sites in pyroxene, each having quite different geometries. This gives rise to strong long-range nonconvergent ordering of $\mathrm{Fe}$ and $\mathrm{Mg}$ between M1 and M2 sites in pyroxene and not in olivine. This last argument shows that micro- $\Phi$ approach between different crystal systems should be used with caution.

\section{Fe-Al mixing in biotite}

All studies that have extracted biotite mixing properties empirically from data on natural assemblages indicate values not more than a few $\mathrm{kJ}$ up to at maximum $\approx 12 \mathrm{~kJ}$ different from zero for the difference $W_{\mathrm{AnnSid}}-W_{\mathrm{PhlEas}},\left(\equiv W_{\mathrm{FeAl}}\right.$ - $W_{\mathrm{MgAl}}$ in older notation Table S1), i.e., both macroscopic $W$ 's describing the interaction of $\mathrm{Fe}$ or $\mathrm{Mg}$ with $\mathrm{Al}$ should give roughly $W$ 's of the same order (both can still be either positive or negative).

The line broadening in powder absorption IR spectra obtained from members of the Ann-Sid binary provides experimental evidence for a negative deviation from ideality for the $\Delta H_{\text {mix }}$-composition behaviour ( $W_{\mathrm{AnnSid}}$ in the order of $-12 \mathrm{~kJ} / \mathrm{mol}$ ). Similar to Phl-Ann, excess entropies along this join are zero. A negative $W_{\mathrm{AnnSid}}=-29 \pm 4 \mathrm{~kJ} /$ mol was proposed by Benisek et al. (1996) derived from reaction displacement experiments on the equilibrium $\mathrm{Ann}=\mathrm{San}+\mathrm{Mag}+\mathrm{H}_{2}$. A less negative value $(-8.2 \mathrm{~kJ} /$ mol) was proposed by Berman et al. (2007). We have set $W_{\text {AnnSid }}$ and $W_{\text {AnnEas }}$ to negative values of $-5 \mathrm{~kJ} / \mathrm{mol}$. This choice reproduces the Al level of a KFMASH biotite with $X_{\mathrm{Mg}}=0.57$ in the assemblage biotite-sillimanite-sanidine-quartz- $\mathrm{H}_{2} \mathrm{O}$, which was experimentally determined by Berman et al. (2007) to lie between 1.78 and $1.83\left(\mathrm{Al}^{\mathrm{VI}}=0.39-0.42\right)$ at $709^{\circ} \mathrm{C} / 2.06 \mathrm{kbar}$ (computed $\mathrm{Al}^{\mathrm{VI}}=0.4$ ). Our result of negative $W_{\text {AnnSid }}$ implies also a negative $W_{\text {EasObi }}$ of the same order due to the equality $W_{\text {EasObi }}=W_{\text {AnnSid }}$ (Powell and Holland 1999; Holland and Powell 2006).

\section{Mg-Al mixing and ordering in biotite}

As discussed in Dachs and Benisek (2019) (their Fig. 10), $\mathrm{Al}$ is highly concentrated on the M1 site of biotite relative to the M2 site, due to the large enthalpy of disordering of $\Delta H_{\text {(eq. 8) }}=34.5 \pm 3 \mathrm{~kJ} / \mathrm{mol}$. Structural data on the ordering of $\mathrm{Al}$ among the two $\mathrm{M}$ sites in natural biotites are highly controversial, for a discussion on the literature data, see Dachs and Benisek (2019). The evaluation of line broadening in powder absorption IR spectra gave two values for the $W_{\text {PhlEas }}$ mixing parameter, namely $25.4 \mathrm{~kJ} / \mathrm{mol}$ (mid-wave number region) and $10 \mathrm{~kJ} / \mathrm{mol}$ (high-wave number region). The larger value was preferred by Dachs and Benisek (2019), because it lead to a good agreement with the solution calorimetric data of Circone and Navrotsky (1992) available for Phl-Eas biotites (Dachs and Benisek (2019), their Fig. 7). Based on our calculations in the KFMASH system, we prefer now the smaller value in combination with $\Delta H_{\text {f.Eas }}^{\mathrm{o}}=-6352.0 \pm 1.4 \mathrm{~kJ} / \mathrm{mol}$. As outlined in Dachs and Benisek (2019) such a $W_{\text {PhlEas }}$ around $10 \mathrm{~kJ} / \mathrm{mol}$ can be considered as minimum value describing nonideality along the Phl-Eas join and reflects the structural situation 
of short-range order. This choice of setting $W_{\text {PhlEas }}=10 \mathrm{~kJ} /$ mol is still in accordance with most of the calorimetric data of Circone and Navrotsky (1992) and produces a moderate temperature dependence of $\mathrm{Al}^{\mathrm{VI}}$ in reasonable agreement with natural observations (Holdaway 1980), showing that the $\mathrm{Al}^{\mathrm{VI}}$ content in biotite from pelitic assemblages should decrease slightly with increasing $T$ (see part-II for more discussion on this). As a consequence, Al ordering on M1 will be even more pronounced than modelled in Dachs and Benisek (2019) and significant amounts of Al on M2 are not to be expected for metamorphic $P-T$ conditions. At temperatures above $1000{ }^{\circ} \mathrm{C}$, however, $\mathrm{Al}$ content on M2 and therefore the proportion of the disordered endmember Easd start rising slightly from values close to zero which could eventually affect the computation of, e.g., mantle equilibria involving Phl-rich biotite.

The enthalpy of $\mathrm{Al}$ ordering on the octahedral sites, $\Delta H_{\text {(eq. 8) }}$, was derived by Dachs and Benisek (2019) from DFT calculations, in which the Al-Si distribution in the tetrahedral sheet of ordered and disordered eastonite (Eas and Easd, respectively) was that of $\mathrm{Al}$ avoidance, i.e., $\mathrm{Al}$ and $\mathrm{Si}$ were alternatively placed in the tetrahedra-ring spanning that sheet. We now did additional DFT calculations for Easd where this constraint was released, allowing a more disordered $\mathrm{Si}-\mathrm{Al}$ distribution. Such configurations lead to still larger $\Delta H_{\text {(eq. 8) }}$ values than $34.5 \mathrm{~kJ} / \mathrm{mol}$. DFT calculations thus indicate that such a $\Delta H_{\text {(eq. 8) }}$ is likely to represent the

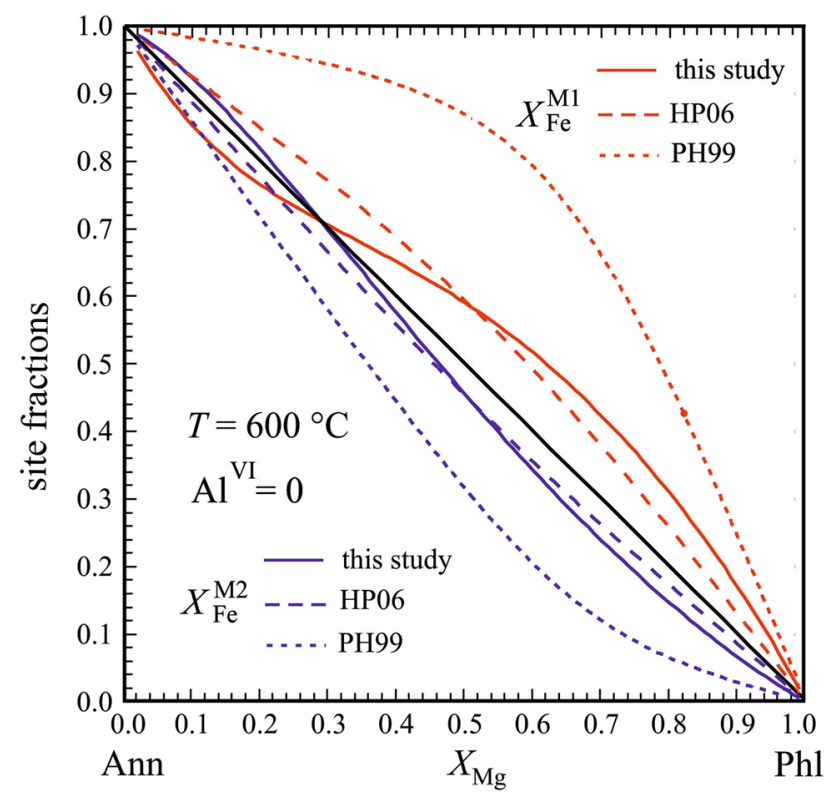

Fig. $7 \mathrm{Fe}-\mathrm{Mg}$ ordering in biotite (solid curves) as resulting from this study $\left(\Delta H_{\text {(eq. 9) }}=-2 \mathrm{~kJ} / \mathrm{mol}\right.$, mixing properties from Table 8): $\mathrm{Fe} /$ $\left(\mathrm{Fe}+\mathrm{Mg}\right.$ ) on $\mathrm{M} 1$ (red) and $\mathrm{Fe} /\left(\mathrm{Fe}+\mathrm{Mg}\right.$ ) on $\mathrm{M} 2$ (blue) vs. bulk $X_{\mathrm{Mg}}$ for $T=600{ }^{\circ} \mathrm{C}(P=1 \mathrm{bar})$. Short/long-dashed curves: Fe-Mg ordering according to Powell and Holland (1999)/Holland and Powell (2006). Black line represents equipartitioning maximum $\mathrm{Mg}-\mathrm{Al}$ disorder to be expected in natural biotites. This confirms the solution space chosen by White et al. (2014a, b), where octahedral Al was assumed to reside on M1 only.

\section{Fe-Mg ordering in biotite and predicted site preferences}

Our KFMASH biotite activity model predicts $\mathrm{Fe}^{2+}$ and $\mathrm{Mg}$ site preferences, as shown in Fig. 7 for $600{ }^{\circ} \mathrm{C}$, where $[\mathrm{Fe} /$ $(\mathrm{Fe}+\mathrm{Mg})]^{\mathrm{M} 1}$ and $[\mathrm{Fe} /(\mathrm{Fe}+\mathrm{Mg})]^{\mathrm{M} 2}$ are plotted as a function of bulk $X_{\mathrm{Mg}}$ in biotite for various $\mathrm{Al}^{\mathrm{VI}}$ levels. From our DFT calculations, we constrained $\Delta H_{\text {(eq. 9) }} \approx-2 \pm 3 \mathrm{~kJ} / \mathrm{mol}$, showing that $\mathrm{Fe}-\mathrm{Mg}$ ordering in biotite should be weak. This confirms assertions of Holland and Powell (2006) and White et al. (2014a) for this value $\left(\Delta H_{\text {(eq. 9) }}=-2 \mathrm{~kJ} / \mathrm{mol}\right)$.

Similar to existing ordering models (Holland and Powell 2006; White et al. 2014a), $\mathrm{Fe}^{2+}$ somewhat prefers the M1 site in biotites with $X_{\mathrm{Mg}}>0.25$. For Fe-rich biotites, a switch in this behaviour occurs. In this compositional range, $\mathrm{Fe}^{2+}$ is slightly enriched in the M2 position. This crossover is a direct consequence of the change in sign in $\Delta G_{\mathrm{ex}}$ from positive to negative in our activity model when going from $\mathrm{Phl}$ towards Ann.

\section{Activity-composition relationships}

The $\mathrm{Phl}$ and Ann activities at $600{ }^{\circ} \mathrm{C}$ vs. bulk $X_{\mathrm{Mg}}$ from this study, for the Ann-Phl binary $\left(\mathrm{Al}^{\mathrm{VI}}=0\right)$ and for $\mathrm{Fe}-\mathrm{Mg}-\mathrm{Al}$ biotites with $\mathrm{Al}^{\mathrm{VI}}=0.3$, are shown in Fig. $8 \mathrm{a}$ and $\mathrm{b}$, respectively. The activities are closer to ideality than would be computed from existing biotite models (Holland and Powell 2006; White et al. 2014a). For these biotite chemistries and at this temperature of $600{ }^{\circ} \mathrm{C}$, our model differs by up to an activity of ca. 0.1 from existing models for biotite. The activities from our modelling are lower by up to this amount, except for the activity of $\mathrm{Phl}\left(a_{\mathrm{Phl}}\right)$ in Mg-rich solid solutions of biotite. The effect of our more ideal biotite activity model on phase relations in the KFMASH system is illustrated in several examples in the companion paper.

\section{Conclusions}

- An important outcome of our study is that excess entropies of mixing are zero for all important biotite binaries (Ann-Phl, Ann-Sid, and Ann-Eas as determined in this work and Phl-Eas as measured by Dachs and Benisek (2019). Excess volumes of mixing are also zero within error for all these joins, so that excess enthalpies are independent of pressure and temperature $\left(W^{\mathrm{G}} \mathrm{ij}=W^{\mathrm{H}}{ }_{\mathrm{ij}}\right)$.

- The thermodynamic analysis of phase-equilibrium data on reactions (17) to (20) gave best-fit results for an asym- 

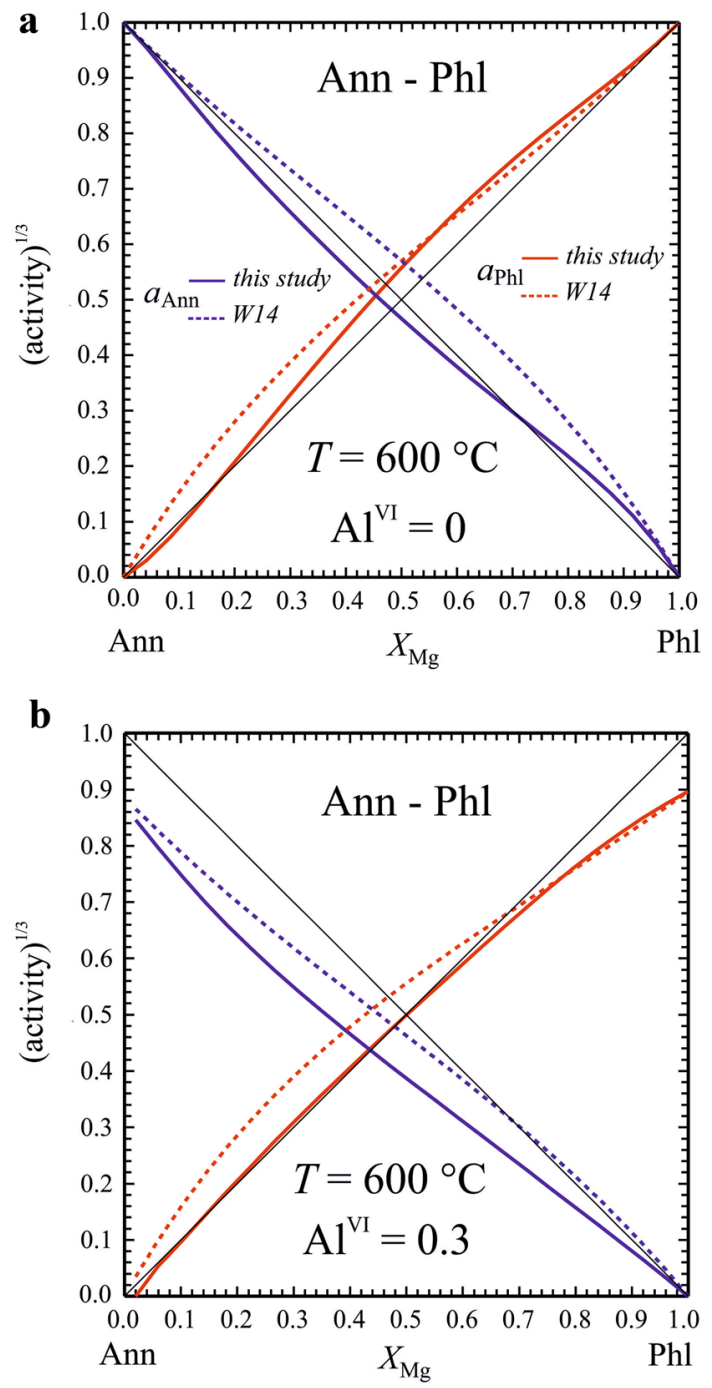

Fig. 8 Activities of Ann (blue) and $\mathrm{Phl}$ (red) at $T=600{ }^{\circ} \mathrm{C}$ for $\mathrm{Al}^{\mathrm{VI}}=0$ apfu (a) and 0.3 (b) as function of bulk $X_{\mathrm{Mg}}(P=1$ bar). Analogous data computed according to White et al. (2014a) are shown for comparison (dashed curves). Black line represents ideality

metric $G_{\text {ex }}$ along the Phl-Ann join, that is negative at Fe-rich and positive at $\mathrm{Mg}$-rich biotite compositions $\left(W^{\mathrm{H}}{ }_{\mathrm{AnnPhl}}=14.3 \pm 3.4 \mathrm{~kJ} / \mathrm{mol}, W^{\mathrm{H}}{ }_{\text {PhlAnn }}=-8.8 \pm 8.0 \mathrm{~kJ} /\right.$ mol). A value of $W_{\text {FaFo }}^{\mathrm{G}}=5 \mathrm{~kJ} / \mathrm{mol}$ for olivine was used in this derivation, which results from published calorimetry, from the majority of phase-equilibrium studies and from our $\Delta$ corr analysis of the line broadening in powder absorption IR spectra of olivine. On the structural level, such a $G_{\text {ex }}$ behaviour for Fe- $\mathrm{Mg}$ mixing in biotite is reasonable, because $\mathrm{Fe}$-rich and $\mathrm{Al}^{\mathrm{VI}}$-poor biotites around the Ann endmember have smaller $\alpha$ 's than $8^{\circ}$ and can reach that value by incorporation of either $\mathrm{Mg}$ or $\mathrm{Al}$ (or $\mathrm{Fe}^{3+}$ ) or both, whereas $\mathrm{Mg}$-rich and $\mathrm{Al}^{\mathrm{VI}}$-poor biotites are already in their 'optimal $\alpha$-state' and a further increase of the Tschermak substitution causes $\alpha$ 's larger than the preferred $8^{\circ}$ value. This behaviour can be modelled with negative deviation from ideality starting at the Ann endmember towards Phl, positive deviation from ideality along the Phl-Eas binary, and a switch from negative to positive deviation for the Ann-Phl binary at intermediate $X_{\mathrm{Mg}}$.

- DFT calculations show that mean octahedral $\mathrm{Fe}-\mathrm{O}$ distances are significantly smaller in pure Ann compared to fayalite and ferrosilite. Annites' octahedral site is thus energetically not comparable to that in fayalite or ferrosilite. Therefore, the micro- $\Phi$ approach between different mineral systems should be used with caution.

- The extracted $\Delta H_{\mathrm{f}, \mathrm{Ann}}^{\mathrm{o}}=-5131.55 \pm 2.34 \mathrm{~kJ} / \mathrm{mol}$ is $13-15 \mathrm{~kJ}$ less negative than published values, which is largely the result of using the revised standard state data for Phl from Dachs and Benisek (2019) in the extraction procedure. Future updates of internally consistent databases, taking this new $\mathrm{Phl}$ standard state data and the experimental data of Zhou (1994) on the $\mathrm{Fe}-\mathrm{Mg}$ partitioning between biotite and olivine into account, are thus expected to yield a similar less negative $\Delta H_{\mathrm{f}, \mathrm{Ann}}^{\mathrm{o}}$, which is compatible with the experimental record from (redox-) equilibria in the FASH system.

- The presently used value of $\Delta H_{(9)}=-2 \mathrm{~kJ} / \mathrm{mol}$ for the reaction $2 / 3 \mathrm{Phl}+1 / 3 \mathrm{Ann}=\mathrm{Obi}$, describing $\mathrm{Fe}-\mathrm{Mg}$ ordering in biotite is confirmed by our DFT calculations that gave values for $\Delta H_{\text {(eq. 9) }} \approx-2 \pm 3 \mathrm{~kJ} / \mathrm{mol}$. Generally, $\mathrm{Fe}-\mathrm{Mg}$ ordering in biotite is thus indicated to be weak.

- The preferred value for $W^{\mathrm{H}}$ PhlEas in this study is $10 \mathrm{~kJ} /$ mol (as used in present biotite activity models), representing strict local charge balance in the structure. It is compatible with an enthalpy of formation of Eas of $\Delta H_{\text {f,Eas }}^{\mathrm{o}}=-6352.0 \pm 3.7 \mathrm{~kJ} / \mathrm{mol}$. Fixing $W^{\mathrm{H}}{ }_{\text {AnnSid }}(\equiv$ $W_{\text {EasObi }}^{\mathrm{H}}$ ) and $W_{\text {AnnEas }}^{\mathrm{H}}$ to $-5 \mathrm{~kJ} / \mathrm{mol}$ gives a moderate temperature dependence of $\mathrm{Al}^{\mathrm{VI}}$ in biotite (i.e., decreasing with $T$ ). Negative excess enthalpies of mixing for the Ann-Sid and Ann-Eas joins are also indicated by evaluating the line broadening in powder absorption IR spectra of members of these binaries.

- Additional DFT calculations on disordered Eas reconfirm the relatively large value of $\Delta H_{\text {(eq. 8) }}=34.5 \mathrm{~kJ} / \mathrm{mol}$ for the disordering of Eas, as given by Dachs and Benisek (2019). In combination with the preferred smaller value for $W_{\text {PhIEas }}=10 \mathrm{~kJ} / \mathrm{mol}$ of this study (compared to $25.4 \mathrm{~kJ} / \mathrm{mol}$ as used in Dachs and Benisek (2019), Mg-Al disordering turns out to be only significant at high temperatures $>1000{ }^{\circ} \mathrm{C}$ in igneous or mantle equilibria. At metamorphic $P-T$ conditions, $\mathrm{Mg}-\mathrm{Al}$ disordering is too small to be of importance and $\mathrm{Al}$ can be taken to reside on M1 only. For that case, our activity model for biotite could be simplified to one where only $\mathrm{Mg}$ and $\mathrm{Fe}^{2+}$ can occupy the M2 site, which is the solution space used by White et al. (2014a) 
- In summary, $\mathrm{Fe}-\mathrm{Mg}$ mixing in biotite departs only slightly and asymmetrically from ideality. In the companion paper, we study the effects of the new biotite activity model and thermodynamic data to phase relations in the KFMASH system, and we analyse the existing, but partly conflicting, experimental $\mathrm{Fe}-\mathrm{Mg}$ exchange data between garnet and biotite.

In a forthcoming paper, we will extend our activity model for KFMASH biotite to include endmembers that account for the presence of excess- $\mathrm{Al}{ }^{\mathrm{VI}}, \mathrm{Ti}$, and $\mathrm{Fe}^{3+}$ in natural biotites.

Supplementary Information The online version contains supplementary material available at https://doi.org/10.1007/s00410-020-01770-5.

Acknowledgements This work was financed by the Austrian Science Fund (FWF) project P28724, which is gratefully acknowledged. We thank E. Forsthofer and colleagues for their professional work in implementing and maintaining the Materials Studio software at the Department of Computer Sciences, Salzburg University, and G. Tippelt for collecting the XRPD patterns. D. Henry (Louisiana State University, USA) is thanked for providing the mineral-chemical data of biotites from Maine. The paper benefited from constructive reviews by R. Sack, B. Myhill, and an anonymous reviewer.

Funding Open Access funding provided by Paris Lodron University of Salzburg.

Open Access This article is licensed under a Creative Commons Attribution 4.0 International License, which permits use, sharing, adaptation, distribution and reproduction in any medium or format, as long as you give appropriate credit to the original author(s) and the source, provide a link to the Creative Commons licence, and indicate if changes were made. The images or other third party material in this article are included in the article's Creative Commons licence, unless indicated otherwise in a credit line to the material. If material is not included in the article's Creative Commons licence and your intended use is not permitted by statutory regulation or exceeds the permitted use, you will need to obtain permission directly from the copyright holder. To view a copy of this licence, visit http://creativecommons.org/licenses/by/4.0/.

\section{References}

Aranovich LY, Newton RC (1998) Reversed determination of the reaction; phlogopite + quartz $=$ enstatite + potassium feldspar $+\mathrm{H}_{2} \mathrm{O}$ in the ranges $750-875$ degrees $\mathrm{C}$ and $2-12 \mathrm{kbar}$ at low $\mathrm{H}_{2} \mathrm{O}$ activity with concentrated $\mathrm{KCl}$ solutions. Am Mineral 83:193-204. https ://doi.org/10.2138/am-1998-3-401

Benisek A, Dachs E (2018) The accuracy of standard enthalpies and entropies for phases of petrological interest derived from densityfunctional calculations. Contrib Mineral Petrol 173:90. https://doi. org/10.1007/s00410-018-1514-x

Benisek A, Dachs E (2020) Excess enthalpy of mixing of mineral solid solutions derived from density-functional calculations. Phys Chem Miner 47:15. https://doi.org/10.1007/s00269-020-01085-8

Benisek A, Dachs E, Redhammer G et al (1996) Activity-composition relationship in Tschermak's substituted Fe biotites at $700^{\circ} \mathrm{C}, 2$ kbar. Contrib Mineral Petrol 125:85-99. https://doi.org/10.1007/ s004100050208
Benisek A, Dachs E, Cemic L (1999) Heat capacities of Tschermak substituted Fe-biotite. Contrib Mineral Petrol 135:53-61. https:// doi.org/10.1007/s004100050497

Benisek A, Dachs E, Kroll H (2010) A ternary feldspar-mixing model based on calorimetric data: development and application. Contrib Mineral Petrol 160:327-337. https://doi.org/10.1007/s00410-009-0480-8

Benisek A, Dachs E, Carpenter MA (2013) Heat capacity and entropy of low structural state plagioclases. Phys Chem Minerals 40:167173. https://doi.org/10.1007/s00269-012-0556-2

Berman RG (1990) Mixing properties of Ca-Mg-Fe-Mn garnets. Am Miner 75:328-344

Berman RG, Aranovich LY (1996) Optimized standard state and solution properties of minerals. Contrib Mineral Petrol 126:1-24. https ://doi.org/10.1007/s004100050232

Berman RG, Aranovich LY, Rancourt DG, Mercier PHJ (2007) Reversed phase equilibrium constraints on the stability of $\mathrm{Mg}$ Fe-Al biotite. Am Mineral 92:139-150. https://doi.org/10.2138/ am.2007.2051

Boffa Ballaran T (2003) Line broadening and enthalpy: some empirical calibrations of solid solution behaviour from IR spectra. Phase Transit 76:137-154. https://doi.org/10.1080/0141159031000076101

Boffa Ballaran T, Carpenter MA, Geiger CA, Koziol AM (1999) Local structural heterogeneity in garnet solid solutions. Phys Chem Miner 26:554-569. https://doi.org/10.1007/s002690050219

Bohlen SR, Boettcher AL, Wall VJ, Clemens JD (1983) Stability of phlogopite-quartz and sanidine-quartz: a model for melting in the lower crust. Contrib Mineral Petrol 83:270-277. https://doi. org/10.1007/BF00371195

Cemič L (2005) The first law of thermodynamics thermodynamics in mineral sciences: an introduction. Springer, Berlin, Heidelberg, pp 78-128

Ceperley DM, Alder BJ (1980) Ground state of the electron gas by a stochastic method. Phys Rev Lett 45:566-569. https://doi. org/10.1103/PhysRevLett.45.566

Circone S, Navrotsky A (1992) Substitution of ${ }^{[6,4]} \mathrm{Al}$ in phlogopite: high-temperature solution calorimetry, heat capacities, and thermodynamic properties of the phlogopite-eastonite join. Am Mineral 77:1191-1205

Clark SJ, Segall MD, Pickard CJ, Hasnip PJ, Probert MIJ, Refson K, Payne MC (2005) First principles methods using CASTEP. Z Kristallogr 220:567-570

Clemens JD (1995) Phlogopite stability in the silica-saturated portion of the system $\mathrm{KAlO}_{2}-\mathrm{MgO}-\mathrm{SiO}_{2}-\mathrm{H}_{2} \mathrm{O}$ : New data and a reappraisal of phase relations to $1.5 \mathrm{GPa}$. Am Mineral 80: 982-997

Dachs E (1994) Annite stability revised. 1. Hydrogen-sensor data for the reaction annite $=$ sanidine + magnetite $+\mathrm{H}_{2}$. Contrib Mineral Petrol 117:229-240. https://doi.org/10.1007/BF00310865

Dachs E, Benisek A (1995) The stability of annite+quartz: reversed experimental data for the reaction 2 annite +3 quartz $=2$ sanidine +3 fayalite $+2 \mathrm{H}_{2} \mathrm{O}$. Contrib Mineral Petrol 121:380-387. https://doi.org/10.1007/s004100050103

Dachs E, Benisek A (2011) A sample-saving method for heat capacity measurements on powders using relaxation calorimetry. Cryogenics 51:460-464. https://doi.org/10.1016/j.cryogenics.2011.04.011

Dachs E, Benisek A (2015) Standard-state thermodynamic properties of annite, $\mathrm{KFe}_{3}\left[(\mathrm{OH})_{2} \mathrm{AlSi}_{3} \mathrm{O}_{10}\right]$, based on new calorimetric measurements. Eur J Mineral 27:603-616. https://doi.org/10.1127/ ejm/2015/0027-2462

Dachs E, Benisek A (2019) A new activity model for $\mathrm{Mg}-\mathrm{Al}$ biotites determined through an integrated approach. Contrib Mineral Petrol 174:76. https://doi.org/10.1007/s00410-019-1606-2

Dachs E, Bertoldi C (2005) Precision and accuracy of the heat-pulse calorimetric technique low-temperature heat capacities of milligram-sized synthetic mineral samples. Eur J Mineral 17:251-261. https://doi.org/10.1127/0935-1221/2005/0017-0251 
Dachs E, Geiger CA, von Seckendorff V, Grodzicki M (2007) A lowtemperature calorimetric study of synthetic (forsterite+fayalite) $\left(\mathrm{Mg}_{2} \mathrm{SiO}_{4}+\mathrm{Fe}_{2} \mathrm{SiO}_{4}\right)$ solid solutions: an analysis of vibrational, magnetic, and electronic contributions to the molar heat capacity and entropy of mixing. J Chem Thermodyn 39:906-933. https:// doi.org/10.1016/j.jct.2006.11.009

Dachs E, Geiger CA, Benisek A (2014a) Thermodynamic mixing properties and behavior of grossular-spessartine, $\left(\mathrm{Ca}_{\mathrm{x}} \mathrm{Mn}_{1-\mathrm{x}}\right)_{3} \mathrm{Al}_{2} \mathrm{Si}_{3} \mathrm{O}_{12}$, solid solutions. Geochim Cosmochim Acta 141:294-302. https://doi.org/10.1016/j.gca.2014.06.034

Dachs E, Geiger CA, Benisek A, Grodzicki M (2014b) Thermodynamic mixing properties and behavior of almandine-spessartine solid solutions. Geochim Cosmochim Acta 125:210-224. https://doi. org/10.1016/j.gca.2013.10.005

Davidson PM, Mukhopadhyay DK (1984) Ca-Fe-Mg olivines: phase relations and a solution model. Contrib Mineral Petrol 86:256263. https://doi.org/10.1007/BF00373671

Etzel K, Benisek A (2008) Thermodynamic mixing behavior of synthetic Ca-Tschermak-diopside pyroxene solid solutions: III. An analysis of IR line broadening and heat of mixing behavior. Phys Chem Miner 35:399-407. https://doi.org/10.1007/s0026 9-008-0234-6

Eugster HP, Wones DR (1962) Stability relations of the ferruginous biotite, annite. J Petrol 3:82-125. https://doi.org/10.1093/petro $\log / 3.1 .82$

Ferry JM, Spear FS (1978) Experimental calibration of the partitioning of $\mathrm{Fe}$ and $\mathrm{Mg}$ between biotite and garnet. Contrib Mineral Petrol 66:113-117. https://doi.org/10.1007/BF00372150

Fonarev VI, Konilov AN (1986) Experimental study of Fe-Mg distribution between biotite and orthopyroxene at $\mathrm{P}=490 \mathrm{MPa}$. Contrib Mineral Petrol 93:227-235. https://doi.org/10.1007/BF00371325

Ganguly J, Cheng W, Tirone M (1996) Thermodynamics of aluminosilicate garnet solid solution: new experimental data, an optimized model, and thermometric applications. Contrib Mineral Petrol 126:137-151. https://doi.org/10.1007/s004100050240

Geiger CA, Newton RC, Kleppa OJ (1987) Enthalpy of mixing of synthetic almandine-grossular and almandine-pyrope garnets from high-temperature solution calorimetry. Geochim Cosmochim Acta 51:1755-1763. https://doi.org/10.1016/0016-7037(87)90353-X

Gessmann CK, Spiering B, Raith M (1997) Experimental study of the $\mathrm{Fe}-\mathrm{Mg}$ exchange between garnet and biotite; constraints on the mixing behavior and analysis of the cation-exchange mechanisms. Am Mineral 82:1225-1240. https://doi.org/10.2138/ am-1997-11-1218

Hazen RM, Burnham CW (1973) The crystal structures of one-layer phlogopite and annite. Am Miner 58:889-900

Hazen RM, Wones DR (1972) The effect of cation substitutions on the physical properties of trioctahedral micas. Am Miner 57:103-129

Hewitt DA, Wones DR (1975) Physical properties of some synthetic Fe-Mg-Al trioctahedral biotites. Am Mineral 60:854-862

Hoisch TD (1991) Equilibria within the mineral assemblage quartz + muscovite + biotite + garnet + plagioclase, and implications for the mixing properties of octahedrally-coordinated cations in muscovite and biotite. Contrib Mineral Petrol 108:43-54. https:// doi.org/10.1007/BF00307325

Holdaway MJ (1980) Chemical formulae and activity models for biotite, muscovite, and chlorite applicable to pelitic metamorphic rocks. Am Miner 65:711-719

Holdaway MJ, Mukhopadhyay B, Dyar MD et al (1997) Garnet-biotite geothermometry revised; new Margules parameters and a natural specimen data set from Maine. Am Mineral 82:582-595. https:// doi.org/10.2138/am-1997-5-618

Holland TJB, Powell R (2006) Mineral activity-composition relations and petrological calculations involving cation equipartition in multisite minerals: a logical inconsistency. J Metamorph Geol 24:851-861. https://doi.org/10.1111/j.1525-1314.2006.00672.x
Holland TJB, Powell R (2011) An improved and extended internally consistent thermodynamic dataset for phases of petrological interest, involving a new equation of state for solids. J Metamorph Geol 29:333-383. https://doi.org/10.1111/j.1525-1314.2010.00923.x

Holland TJB, Redfern S, AT (1997) Unit cell refinement from powder diffraction data: the use of regression diagnostics. Mineral Mag 61:65-77. https://doi.org/10.1180/minmag.1997.061.404.07

Indares A, Martignole J (1985) Biotite-garnet geothermometry in the granulite facies: the influence of $\mathrm{Ti}$ and $\mathrm{Al}$ in biotite. Am Mineral 70:272-278

Jackson SL (1989) Extension of Wohl's ternary asymmetric solution model to four and $\mathrm{n}$ components. Am Mineral 74:14-17

Jenkins DM, Carpenter MA, Zhang M (2014) Experimental and infrared characterization of the miscibility gap along the tremolite-glaucophane join. Am Miner 99:730-741. https://doi.org/10.2138/am.2014.4590

Kennedy CA, Stancescu M, Marriott RA, White MA (2007) Recommendations for accurate heat capacity measurements using a Quantum Design physical property measurement system. Cryogenics 47:107-112. https://doi.org/10.1016/j.cryogenics .2006.10.001

Kleemann U, Reinhardt J (1994) Garnet-biotite thermometry revisited: The effect of $\mathrm{Al}^{\mathrm{VI}}$ and $\mathrm{Ti}$ in biotite. Eur J Mineral 6:925-942

Kojitani H, Akaogi M (1994) Calorimetric study of olivine solid solutions in the system $\mathrm{Mg}_{2} \mathrm{SiO}_{4}-\mathrm{Fe}_{2} \mathrm{SiO}_{4}$. Phys Chem Miner 20:536540. https://doi.org/10.1007/BF00211849

Lashley JC, Hundley MF, Migliori A et al (2003) Critical examination of heat capacity measurements made on a Quantum Design physical property measurement system. Cryogenics 43:369-378. https ://doi.org/10.1016/S0011-2275(03)00092-4

Li Y, Kowalski PM, Blanca-Romero A et al (2014) Ab initio calculation of excess properties of $\mathrm{La}_{1-\mathrm{x}}(\mathrm{Ln}, \mathrm{An})_{\mathrm{x}} \mathrm{PO}_{4}$ solid solutions. J Solid State Chem 220:137-141. https://doi.org/10.1016/j. jssc.2014.08.005

McMullin DW, Berman RG, Greenwood HJ (1991) Calibration of the SGAM thermobarometer for pelitic rocks using data from phaseequilibrium experiments and natural assemblages. Can Mineral 29:889-908

Mercier PHJ (2006) Upper limit of the tetrahedral rotation angle and factors affecting octahedral flattening in synthetic and natural $1 \mathrm{M}$ polytype C2/m space group micas. Am Mineral 91:831-849. https ://doi.org/10.2138/am.2006.1815

Monkhorst HJ, Pack JD (1976) Special points for Brillouin-zone integrations. Phys Rev B 13:5188-5192. https://doi.org/10.1103/ PhysRevB.13.5188

Müller RF (1972) Stability of biotite: a discussion. Am Mineral 57:300-316

Perchuk LL, Lavrent'eva IV (1983) Experimental investigation of exchange equilibria in the system cordierite-garnet-biotite. In: Saxena SK (ed) Kinetics and equilibrium in mineral reactions. Springer, New York, pp 199-239

Pfrommer BG, Côté M, Louie SG, Cohen ML (1997) Relaxation of crystals with the quasi-newton method. J Comput Phys 131:233240. https://doi.org/10.1006/jcph.1996.5612

Powell R, Holland T (1999) Relating formulations of the thermodynamics of mineral solid solutions; activity modeling of pyroxenes, amphiboles, and micas. Am Mineral 84:1-14. https://doi. org/10.2138/am-1999-1-201

Powell R, White RW, Green ECR et al (2014) On parameterizing thermodynamic descriptions of minerals for petrological calculations. J Metamorph Geol 32:245-260. https://doi.org/10.1111/ jmg. 12070

Redhammer GJ, Beran A, Dachs E, Amthauer G (1993) A Mössbauer and X-ray diffraction study of annites synthesized at different oxygen fugacities and crystal chemical implications. Phys Chem Miner 20:382-394. https://doi.org/10.1007/BF00203107 
Redhammer GJ, Dachs E, Amthauer G (1995) Mössbauer spectroscopic and $\mathrm{x}$-ray powder diffraction studies of synthetic micas on the join annite $\mathrm{KFe}_{3} \mathrm{AlSi}_{3} \mathrm{O}_{10}(\mathrm{OH})_{2}$-phlogopite $\mathrm{KMg}_{3} \mathrm{AlSi}_{3} \mathrm{O}_{10}(\mathrm{OH})_{2}$. Phys Chem Miner 22:282-294. https://doi.org/10.1007/BF002 02768

Redhammer GJ, Beran A, Schneider J et al (2000) Spectroscopic and structural properties of synthetic micas on the annite-siderophyllite binary: synthesis, crystal structure refinement, Mössbauer, and infrared spectroscopy. Am Mineral 85:449-465. https://doi. org/10.2138/am-2000-0406

Redhammer GJ, Amthauer G, Lottermoser W et al (2005) X-ray powder diffraction and 57Fe - Mössbauer spectroscopy of synthetic trioctahedral micas $\{\mathrm{K}\}\left[\mathrm{Me}_{3}\right]\left\langle\mathrm{TSi}_{3}\right\rangle \mathrm{O}_{10}(\mathrm{OH})_{2}, \mathrm{Me}=\mathrm{Ni}^{2+}, \mathrm{Mg}^{2+}$, $\mathrm{Co}^{2+}, \mathrm{Fe}^{2+} ; \mathrm{T}=\mathrm{Al}^{3+}, \mathrm{Fe}^{3+}$. Mineral Petrol 85:89-115. https://doi. org/10.1007/s00710-005-0096-2

Robie RA, Hemingway BS (1984) Heat capacities and entropies of phlogopite $\left(\mathrm{KMg}_{3}\left[\mathrm{AlSi}_{3} \mathrm{O}_{10}\right](\mathrm{OH})_{2}\right)$ and paragonite $\left(\mathrm{NaAl}_{2}\left[\mathrm{AlSi}_{3} \mathrm{O}_{10}\right](\mathrm{OH})_{2}\right)$ between 5 and $900 \mathrm{~K}$ and estimates of the enthalpies and Gibbs free energies of formation. Am Mineral 69:858-868

Rodriguez-Carvajal J (2001) Recent developments of the program FULLPROF, commission on powder diffraction. IUCr Newsl 26:334

Sack RO (1980) Some constraints on the thermodynamic mixing properties of $\mathrm{Fe}-\mathrm{Mg}$ orthopyroxenes and olivines. Contrib Mineral Petrol 71:257-269. https://doi.org/10.1007/BF00371667

Sack RO, Ghiorso MS (1989) Importance of considerations of mixing properties in establishing an internally consistent thermodynamic database: thermochemistry of minerals in the system $\mathrm{Mg}_{2} \mathrm{SiO}_{4}-\mathrm{Fe}_{2} \mathrm{SiO}_{4}-\mathrm{SiO}_{2}$. Contrib Mineral Petrol 102:41-68. https ://doi.org/10.1007/BF01160190

Salje EKH, Carpenter MA, Malcherek T, Boffa Ballaran $\mathrm{T}$ (2000) Autocorrelation analysis of infrared spectra from minerals. Eur J Mineral 12:503-519. https://doi. org/10.1127/0935-1221/2000/0012-0503

Schulien S (1980) Mg-Fe partitioning between biotite and a supercritical chloride solution. Contrib Mineral Petrol 74:85-93. https://doi. org/10.1007/BF00375492

Sluiter MHF, Kawazoe Y (2002) Prediction of the mixing enthalpy of alloys. Europhys Lett 57:526. https://doi.org/10.1209/epl/i2002 $-00493-3$

Tajčmanová L, Connolly JAD, Cesare B (2009) A thermodynamic model for titanium and ferric iron solution in biotite. J Metamorph Geol 27:153-165

\section{Authors and Affiliations}

\section{Edgar Dachs $^{1}$ (D) $\cdot$ Artur Benisek $^{1}$}

Edgar Dachs

edgar.dachs@sbg.ac.at
Tarantino SC, Carpenter MA, Domeneghetti MC (2003) Strain and local heterogeneity in the forsterite-fayalite solid solution. Phys Chem Minerals 30:495-502. https://doi.org/10.1007/s0026 9-003-0357-8

White P, Holland W (2000) The effect of $\mathrm{TiO}_{2}$ and $\mathrm{Fe}_{2} \mathrm{O}_{3}$ on metapelitic assemblages at greenschist and amphibolite facies conditions: mineral equilibria calculations in the system $\mathrm{K}_{2} \mathrm{O}-\mathrm{FeO}-\mathrm{MgO}$ $\mathrm{Al}_{2} \mathrm{O}_{3}-\mathrm{SiO}_{2}-\mathrm{H}_{2} \mathrm{O}-\mathrm{TiO}_{2}-\mathrm{Fe}_{2} \mathrm{O}_{3}$. J Metamorph Geol 18:497-511. https://doi.org/10.1046/j.1525-1314.2000.00269.x

White RW, Powell R, Holland TJB (2007) Progress relating to calculation of partial melting equilibria for metapelites. J Metamorph Geol 25:511-527

White RW, Powell R, Holland TJB et al (2014a) New mineral activity-composition relations for thermodynamic calculations in metapelitic systems. J Metamorph Geol 32:261-286. https://doi. org/10.1111/jmg.12071

White RW, Powell R, Johnson TE (2014b) The effect of Mn on mineral stability in metapelites revisited: new $a-x$ relations for manganese-bearing minerals. J Metamorph Geol 32:809-828. https:// doi.org/10.1111/jmg.12095

Wiser NM, Wood BJ (1991) Experimental determination of activities in Fe-Mg olivine at $1400 \mathrm{~K}$. Contrib Mineral Petrol 108:146-153. https://doi.org/10.1007/BF00307333

Wohl K (1946) Thermodynamic evaluation of binary and ternary liquid systems. Trans Am Inst Chem Eng 42:215-249

Wohl K (1953) Thermodynamic evaluation of binary and ternary liquid systems. Chem Eng Prog 49:218-221

Wones DR (1972) Stability of biotite: a reply. Am Mineral 57:316-317

Wones DR, Eugster HP (1965) Stability of biotite: experiment, theory and application. Am Mineral 50:1228-1272

Wood BJ, Kleppa OJ (1981) Thermochemistry of forsterite-fayalite olivine solutions. Geochim Cosmochim Acta 45:529-534. https ://doi.org/10.1016/0016-7037(81)90185-X

Zhou F (1994) Ti-Mg-Fe biotites: formation, substitution, and thermodynamic properties at 650 to $900{ }^{\circ} \mathrm{C}$ and $1.1 \mathrm{~Kb}$ with fO2 defined by the $\mathrm{CH} 4$-graphite buffer. PhD Thesis, State University of New York

Zhou F, Cococcioni M, Marianetti CA, Morgan D, Ceder G (2004) First-principles prediction of redox potentials in transition-metal compounds with LDA+U. Phys Rev B 70:235121

Publisher's Note Springer Nature remains neutral with regard to jurisdictional claims in published maps and institutional affiliations.
Fachbereich Chemie und Physik der Materialien, Abteilung Mineralogie, Universität Salzburg, Jakob-Haringerstrasse 2a, 5020 Salzburg, Austria 